\title{
Financial Development, Financial Constraints, and the Volatility of Industrial Output
}

\author{
Borja Larrain
}

\begin{abstract}
:
Countries with higher financial development show lower volatility of industrial output. Volatility is particularly reduced in industries that are more financially dependent. Most of the reduction is in idiosyncratic volatility. Systematic volatility is reduced less strongly, implying that industries are more closely correlated with GDP in more financially developed countries. At the firm level, short-term debt is negatively correlated with output as financial development increases, suggesting that debt is used in a countercyclical way to stabilize production. The results indicate that financial development relaxes financial constraints mainly to smooth negative cash-flow shocks.
\end{abstract}

Keywords: financial development, financial constraints, volatility

JEL Classifications: E32, G0, G31, O16

Borja Larrain is an Economist at the Federal Reserve Bank of Boston. His e-mail address is borja.larrain@bos.frb.org

This paper, which may be revised, is available on the web site of the Federal Reserve Bank of Boston at http://www.bos.frb.org/economic/ppdp/index.htm.

The views expressed in this paper are solely those of the author and do not reflect official positions of the Federal Reserve Bank of Boston or the Federal Reserve System.

This paper is based on the second chapter of the author's dissertation at Harvard University. He thanks his thesis advisers John Campbell, Andrei Shleifer, and Jeremy Stein for their support and guidance throughout the project, as well as Miklós Koren, Krishna Kumar, John Matsusaka, Gustavo Suárez, Adam Szeidl, Francesco Trebbi, Motohiro Yogo, and seminar participants at the Federal Bank of Boston, Harvard University, IESE, Ohio State University, the University of Michigan, and the University of Southern California for helpful comments. The author is grateful to Matías Braun for many conversations that have been central for his understanding of financial development and business cycles. All errors remain his.

This version: July 2004

First draft: August 2003 


\section{Introduction}

There is substantial evidence that industrial output is less volatile in developed countries than in less developed countries, although the evidence is focused on macroeconomic aggregates. See, for example, the recent paper by Acemoglu et al. (2003), which also surveys part of the literature. The present paper uses micro data (industry-level and firm-level data) to study volatility and, in particular, the effect of financial development on volatility. The advantage of using micro data lies in allowing a more detailed exploration of the mechanisms behind financial development. Using micro data also enables one to study the composition of the changes in volatility in terms of idiosyncratic and systematic (country-level) components.

The mechanism studied in this paper is that financial development allows firms to borrow more freely by relaxing financial constraints. These financial constraints arise from agency problems and asymmetric information, which are ameliorated as financial development increases. A large body of literature studies the impact of financial constraints on real activity. (See the surveys by Hubbard 1998 and Stein 2003). The literature shows that the financial position of a firm has important implications for capital expenditures, inventory accumulation, employment, pricing strategies, and other factors. The basic conclusion is the same in every case, namely, that financial constraints can prevent a firm from undertaking profitable investment opportunities. This paper adds fresh evidence to the literature on financial constraints with three distinctive features:

First, the focus of this paper is on short-run output fluctuations-in particular, the volatility of industrial output and its composition. The previous literature focuses instead on long-run growth. (See Levine 1997.)

Second, the interaction of financial development and volatility provides a unique opportunity to study the interplay of financial constraints and different types of shocks. This paper develops a simple model showing that the effect of financial development on output volatility is, in fact, ambiguous: The effect depends on the circumstances causing 
constraint. In other words, what use do firms make of the extra funds borrowed from a more developed financial system? If firms need funds to smooth unfavorable cash-flow shocks, financial development reduces output volatility. On the other hand, if firms need funds to expand their production when confronted with a positive investment opportunity, financial development increases output volatility. Therefore, knowing whether the effect of financial development on volatility is positive or negative provides information about the shocks that firms are trying to manage-telling us whether these are primarily shocks to their resources or shocks to their opportunities-and also gives us a sense of how financial development helps firms. This is important for the discussion about the relative importance of cash-flow versus investment-opportunity shocks-a discussion endemic to the corporate finance literature on financial constraints.

A third distinctive feature is that the empirical model employs cross-country as well as within-country comparisons among industries to identify the effects of financial development on industrial volatility. This identification strategy is borrowed from Rajan and Zingales (1998, hereafter RZ), who study long-run industrial growth and its relation to financial development. RZ identify from an a priori base those industries that are especially dependent on external financing and that consequently should benefit more from financial development. The use of an industry-level ranking of financial constraints can ease some of the difficulties encountered when measuring constraints at the firm level. Many firm-level variables that are usually considered to be indicators of financial constraint (such as size or investment-cash flow sensitivities) are hopelessly endogenous. An industry-based measure is arguably more exogenous or driven by technological considerations.

The first finding is that financial development reduces output volatility. This is not surprising, given the macro evidence already available, but now this finding is confirmed by micro evidence-with an extra layer of robustness provided by comparisons between more and less financially constrained industries. The fact that volatility is reduced suggests that firms face shocks mainly to their cash flows and that 
as financial development increases, they are able to smooth a larger fraction of these shocks.

A contribution of this paper is that it explores the anatomy of volatility reduction. Output volatility is decomposed into systematic and idiosyncratic components, where idiosyncratic volatility is defined as industry volatility uncorrelated with the GDP of the country where the industry is located. Systematic and idiosyncratic volatility fall with financial development, but the fall in idiosyncratic volatility is greater. As a share of total volatility, idiosyncratic volatility is, then, smaller in more financially developed countries. This result comes from the advantage that financial intermediaries have in smoothing idiosyncratic shocks: Intermediaries operate by pooling and subdividing risks among many agents-something that is harder to do with large-scale shocks. The intuition for this result can be illustrated with a simple example: Imagine that there are three industries in a country and that there is a financial system willing to lend an amount $X$. If one industry is hit by a shock of magnitude $X$, it can borrow and smooth the shock completely. On the other hand, if the three industries are hit by the same shock $X$ (for example, a recession), they are able to borrow just one-third of the amount needed and therefore can smooth only one-third of the shock. In this simple example, idiosyncratic volatility falls in a one-to-one relationship with increasing financial depth (the amount of credit available), but systematic volatility falls by just one-third. An important piece of the argument is that the financial system is, in some sense, hindered from raising more capital during the aggregate shock or recession, limiting the amount of the shock that can be absorbed and spread among various investors.

The last section of the paper turns to firm-level data to explore in more detail the mechanism through which volatility is reduced. The finding of reduced volatility is examined by looking at sales volatility and, more importantly, by examining the connection between a firm's activity and its borrowing. An important finding is that short-term debt is more negatively correlated with sales as financial development increases, suggesting that short-term debt is used to smooth production. Again, this 
effect is stronger in firms that belong to more financially constrained industries, even after controlling for other industry, country, and firm characteristics. The firm-level evidence is important in showing that production shocks do not disappear, but that they are effectively buffered by the financial system.

This paper is related to work done by Raddatz (2002), who also studies volatility using a strategy that closely follows that of RZ. Raddatz develops a measure of liquidity needs and shows that financial development reduces volatility more strongly in liquidity-dependent sectors. He does not look at the composition of volatility or the borrowing side, and he does not draw conclusions about the underlying structure of cash-flow versus investment-opportunity shocks.

The organization of this paper is as follows. Section 2 provides a theoretical framework to understand the main hypotheses. Section 3 describes the empirical strategy and the data sources. Section 4 presents the main result and robustness checks, using industry data. Section 5 examines the decomposition of industrial volatility. Section 6 explores the mechanism behind the reduction in volatility using firm-level data. Section 7 concludes.

\section{Financial development, financial constraints and volatility: theoretical framework}

\subsection{Basic setup}

The main purpose of the model is to show that the effect on output volatility of increasing financial development is a function of the structure of the underlying shocks and, therefore, of the circumstances under which financial constraints are more binding. Another way to put this is that financial development has different effects on fluctuations depending on when borrowing is more needed. If borrowing is mostly needed for rapid expansion, higher financial development increases volatility. On the other hand, if borrowing is mostly needed to sustain output in a period of falling cash flow, higher financial development decreases volatility. 
Think of a firm with a production function $Y=\theta \mathrm{F}(I)$, where $\theta$ is a productivity shock, $I$ is investment, and $F(I)$ is increasing and concave. The firm's budget constraint for investment is:

$$
I \leq \omega W+E .
$$

$W$ is the average amount of internal funds available to the firm. Internal funds vary according to the realization of the cash-flow shock $\omega$. E represents external funds from equity issues, bank loans, credit lines, or other sources.

Equation (1) is not really a constraint in a perfect capital market since in such a market the firm can borrow (or lend) as much as it needs to implement the optimal investment plan. In order to give a role to financial development, the assumption is introduced that financial markets are imperfect in the sense that firms face an upper limit on borrowing. Therefore,

$$
E \leq E(K)
$$

No more funds than $E(K)$ are supplied to the firm. $K$ is the indicator of financial development, where a more developed financial system implies that more funds are available for borrowing, that is, $E_{K}>0$.

A borrowing constraint like the one in (2) can originate in any of several ways. Take, for instance, the model of imperfect contracting by Hart and Moore (1994). In that model, the firm can divert resources from a project since it is unverifiable to a third party, such as a court of law. Despite this, the ownership of assets is transferable to the lender if the firm does not pay its debts. In such a world, all borrowing is secured by assets that can be transferred to creditors, that is, by collateral. Under this interpretation, $E(K)$ is the amount of collateral available for external financiers to seize in the event of nonpayment. Simply put, $E(K)$ can be understood as the amount creditors can expect to recoup from their investment: The more they expect to recoup, the more they lend. In this setting, $\mathrm{K}$ can represent the enforceability of creditor rights, where a more developed financial system has a higher degree of enforceability than a less developed one. More generally, $K$ embodies various types of friction. (A high $K$ means lower friction or higher financial 
development.) Some types of friction include informational asymmetry about the quality of projects (Myers and Majluf 1984) and costs of bankruptcy and auditing (Townsend 1979).

Given realization of the productivity and cash-flow shocks, the firm's program consists of maximizing the net present value of investment subject to the financial constraint.

$\operatorname{Max} \quad \theta \mathrm{F}(I)-R I$

Subject to $\quad I \leq \omega W+E(K)$,

where $R$ is the cost of external funds per unit borrowed.

When the financial constraint is not binding, the firm optimally invests $I^{*}$, implicitly defined by the first-order condition $\theta F^{\prime}\left(I^{*}\right)=R$. When the financial constraint is binding, the firm can invest only $I^{c} \equiv \omega W+E(K)<I^{*}$.

Despite its simplicity, this model gives different predictions about the effect of financial development on volatility, depending on the structure of shocks $\{\theta, \omega\}$. The rest of this section analyzes the predictions under different shock regimes.

\subsection{Only cash-flow shocks}

Assume that there are two possible states of nature $\omega^{h}$ and $\omega^{l}$, a high-cash-flow state and a low-cash-flow state, respectively, where $\omega^{h}>\omega^{l}>0$. The low-cash-flow state occurs with probability $p .^{1}$ Investment opportunities, or $\theta$, are constant. It is easy to see that the borrowing constraint is more binding during the low-cash-flow state since investment opportunities are constant. Assume, furthermore, that the firm is constrained in the lowcash-flow state and unconstrained in the high-cash-flow state. In this case, the variance of output is $\sigma^{2}=p(1-p) \theta^{2}\left[F\left(I^{*}\right)-F\left(I^{c}\right)\right]^{2}$. The intuition for this expression is simple: The more constrained the firm is in the low-cash-flow state, the larger the reduction in production as compared with the high-cash-flow state and, therefore, the higher the

\footnotetext{
${ }^{1}$ It is assumed that $(1-p) \omega^{h}+p \omega^{l}=1$. This condition is just a normalization so that $W$ is the average amount of internal funds.
} 
volatility. The effects of increasing financial development, $K$, in this two-state model are summarized in the next proposition. (All the proofs involve simple algebra so they are omitted.)

Proposition 1: When there are only cash-flow shocks, an increase in financial development reduces the volatility of output $\left(\partial \sigma^{2} / \partial K<0\right)$. If a firm is constrained in the low-cash-flow state and unconstrained in the high-cash-flow state, then the marginal effect of financial development is smaller in magnitude for a firm with high average internal funds than for a firm with low average internal funds $\left(\partial^{2} \sigma^{2} / \partial K \partial W>0\right)$.

In this case, financial development and internal funds reduce volatility by increasing production in the more constrained state. The effect of financial development is smaller in firms with high internal funds since the funds act as a substitute for financial development: A firm with high internal funds already has low volatility.

\subsection{Only investment-opportunity shocks}

Now assume that there are two possible states, $\theta^{h}$ and $\theta^{l}$, a high-productivity state and a low-productivity state, respectively, where $\theta^{h}>\theta^{l}>0$. The high-productivity state occurs with probability $p$. In this case there is variation only in investment opportunities and no variation in internal funds. The borrowing constraint is more likely to bind in the high-productivity state since desired investment is higher and the level of internal cash flow is the same. For simplicity, consider the case where the firm is constrained during the high-productivity state and unconstrained during the low-productivity state. ${ }^{2}$ The resulting variance of output is $\sigma^{2}=p(1-p)\left[\theta^{h} F\left(I^{c}\right)-\theta^{l} F\left(I^{*}\right)\right]^{2}$. Now volatility comes from the ability to increase production when productivity is high: The less binding the borrowing constraint in the high-productivity state, the more volatility the firm is able to manage. The effects of increasing financial development, $K$, under this regime are summarized in the next proposition.

\footnotetext{
${ }^{2} \mathrm{Ic}^{\mathrm{c}}$ and $\mathrm{I}^{*}$ are still used in this case to refer to the constrained and unconstrained levels of investment, respectively, but keep in mind that the unconstrained level now depends on realization of the productivity shock.
} 
Proposition 2: When there are only productivity shocks, and if the firm is constrained during the high-productivity state and unconstrained during the low-productivity state, an increase in financial development increases the volatility of output $\left(\partial \sigma^{2} / \partial K>0\right)$. The cross derivative, $\partial^{2} \sigma^{2} / \partial K \partial W$, has an ambiguous sign.

The cross derivative, $\partial^{2} \sigma^{2} / \partial K \partial W$, is ambiguous because of diminishing returns to investment. The effect is negative if diminishing returns are sufficiently strong, meaning that the increase in volatility is smaller for firms with high levels of internal funds.

\subsection{What shocks dominate (or when are financial constraints more binding)?}

In practice, cash-flow shocks and productivity shocks are probably positively correlated, making it difficult to disentangle them empirically. For instance, lower cash flows can coincide with periods of poor investment opportunities. Efforts have been made to identify quasi-natural experiments where we are certain of the shock that hits the firm; for instance, Blanchard, Lopez-de-Silanes, and Shleifer (1994) examine a small sample of pure cash-flow windfalls brought by lawsuits. In general, cash-flow and investment opportunity shocks are not easily identifiable by their sources, at least in terms of the sources common to the literature on business cycles, such as monetary policy or technology. For example, a monetary policy shock can impact cash flows and investment opportunities at the same time.

Despite the difficulties, the change in output volatility as a response to better financial development is informative about the underlying structure of shocks. In particular, "When are financial constraints more binding?" is the same question as "What shocks are dominant?" If investment-opportunity shocks are dominant--think of dominant as having higher amplitude-then financial constraints are more binding during good times (times of high cash flows and high productivity). The extreme of this is proposition 2, with constant cash flows. Conversely, if cash-flow shocks are dominant, then financial constraints are more binding during bad times (low cash flows and low 
productivity). The effect of financial development on output volatility is the opposite in the two scenarios, as summarized in the next proposition.

Proposition 3: In the model with two states, positively correlated cash-flow and productivity shocks, if financial constraints are binding only during bad times (low $\theta$, low $\omega)$, an increase in financial development reduces the volatility of output $\left(\partial \sigma^{2} / \partial K<0\right)$. In this case, the marginal effect of financial development is smaller in magnitude for firms with high levels of internal funds than in firms with low levels of internal funds $\left(\partial^{2} \sigma^{2} / \partial K \partial W>0\right)$. If financial constraints are binding only during good times (high $\theta$, high $\omega$ ), an increase in financial development increases the volatility of output $\left(\partial \sigma^{2} / \partial K>0\right)$. In this second case, the cross derivative, $\partial^{2} \sigma^{2} / \partial K \partial W$, has an ambiguous sign.

Financial development allows firms to borrow more freely when their need is greatest. If bad times, that is, recessions, are times of tighter financial constraint, then higher financial development allows firms to sustain levels of production that are closer to the production levels of good times, thereby reducing overall volatility. This is the case when the fall in cash flows during bad times is greater than the decline in investment opportunities and when the resulting financing gap is larger than the one experienced during good times. On the other hand, if good times, that is, expansions, are times of tighter financial constraint, then higher financial development allows firms to expand their production rapidly, thereby increasing volatility. The answer to the question of which view of the world is more appropriate-a world dominated by cash-flow shocks or a world dominated by investment-opportunity shocks-can give important insights not only to finance, but also to business cycle theories and policy work.

It is interesting to look at the behavior of credit. In both scenarios, the volatility of credit increases with financial development, either to allow for higher output volatility or to absorb output volatility, depending on whether financial constraints are more binding during good or bad times. But the implications are different in terms of the correlation of credit with output. If financial development reduces output volatility, it is because credit behaves in a countercyclical way (negatively correlated with activity). On the contrary, an 
increase in output volatility is accompanied by procyclical credit (positively correlated with activity). In this simple model, the correlation between credit and output is either 1 or -1 , depending on the scenario; in a richer model we would expect these correlations to increase or decrease with the level of financial development. ${ }^{3}$ In fact, according to evidence in Galindo, Micco, and Suárez (2003), credit is less procyclical in more developed financial systems (as proxied by the degree of creditors' rights), a condition that supports the idea that financial development is needed mostly to sustain higher levels of production during periods of bad economic conditions-in other words, to smooth cashflow shocks.

\subsection{Caveats}

An important caveat, first noted by Kaplan and Zingales (1997), is that predictions of models with financial constraints are cleaner in terms of first derivatives than in terms of cross derivatives, such as $\partial^{2} \sigma^{2} / \partial K \partial W$. Propositions 2 and 3 reflect this fact. The empirical part of this paper focuses on both implications of the model, and not just on second derivatives, which might be misleading if considered in isolation.

A second caveat is that we need the assumption that the firm is unconstrained in one state of the world for the results to go through without any further restrictions (except for the first part of proposition 1). If the firm is constrained in both states, the effects produce ambiguous signs, and they depend on the relationship between the derivatives of $F(I)$ and the magnitude of the shocks.

Finally, note that the model presented here is a reduced form of one of the leading models in corporate finance. ${ }^{4}$ Other complementary models interpret greater financial development as a way of tightening financial constraints during good times, which are

\footnotetext{
${ }^{3}$ The covariance between output and borrowing, which is another measure of co-movement, is definitely increasing in the case of pure investment-opportunity shocks, but is not clear in the case of only cash-flow shocks. Only this second case allows for a decreasing covariance. ${ }^{4}$ Other important models can be expressed in a reduced form with a wealth multiplier equation. See Stein (2003). Basically, investment is some fraction of internal wealth $(I=k W)$, where the multiplier $k$ increases with financial development. In this case, volatility rises with financial development since it amplifies the swings in internal wealth.
} 
more prone to agency problems. Managers can overinvest during expansions for empirebuilding reasons, or perhaps undertake very volatile projects if the residual claim of shareholders is already small (Stein 2003). In these models, financial development can reduce volatility by restraining agency-related expansion, and we still find that volatility is reduced by closing (rather than by increasing) the gap between the borrowing levels of bad times and good times, or, in other words, by making the provision of credit less procyclical. Despite the similarity of this prediction to the findings of this paper, note that the policy or welfare implications of the model presented here can be quite different from those of an empire-building model.

\section{Empirical strategy}

\subsection{Empirical model}

In order to test the predictions of the model, the following two equations are estimated, using regression analysis:

Std. deviation ${ }_{i, c}=\alpha_{1}$ Financial development $_{c}+\alpha_{2}$ Country controls $_{c}+\alpha_{3}$ Industry dummies $_{i}+\varepsilon_{i, c}$

Std. deviation ${ }_{i, c}=\beta_{1}\left(\right.$ Financial development $_{c} *$ Financial dependence $\left._{i}\right)+\beta_{2}$ Country dummies $_{c}$

$$
+\beta_{3} \text { Industry dummies }_{i}+\xi_{i, c} \text {. }
$$

Bold Greek letters represent vectors of coefficients in equations (4) and (5). The dependent variable is the standard deviation of cyclical output of industry $i$ in country $c$. The standard deviation of the detrended output is computed for each industry. Regression analysis of equation (4) tests the direct effect of financial development on industrial volatility, controlling for other country characteristics and industry fixed effects. The country controls are average per capita GDP, average government expenditures as a percentage of GDP, and the country's openness according to the Frankel and Romer (1999) index. 
Equation (5) includes country and industry dummies to control for any unobservable characteristic at the country and industry levels. The country fixed effects now absorb the direct effect of financial development. The coefficient of interest in (5) accompanies the interaction of financial development with financial dependence (the RZ index), which represents the cross derivative, $\partial^{2} \sigma^{2} / \partial K \partial W$. According to proposition 3, $\beta_{1}$ should be negative if financial development reduces volatility on average. If financial development increases volatility, the sign is ambiguous. Results are also reported using the interaction of financial development with high financial dependence, a dummy that takes the value one if industry $i$ is above the median in the ranking of financial dependence, and zero otherwise. Because of quality-of-data considerations, the error terms are allowed to be heteroskedastic and correlated among industries of the same country.

Two sources of measurement error can lead to problems. First, standard deviations are sample moments and not population moments, so they are measured with error. Using a sufficiently long time series mitigates this problem. In the industry sample, more than 75 percent of the moments are computed with 31 years of detrended data, and none with less than 20 years. The residual measurement error can cause problems if it is correlated with the explanatory variables, although this does not seem probable; otherwise, it will increase the standard errors but will not violate any of the OLS assumptions. Instrumental variables can also address this concern. A second type of measurement error is in the index of financial dependence. This can cause attenuation bias, that is, the coefficients may be biased towards zero. An attempt is made to minimize this error by splitting the industries into just two groups (highdependence and low-dependence).

Note that these are purely cross-sectional regressions and, as such, they ignore changes in volatility and financial development over time. This approach is taken because computing volatilities for short periods would increase the measurement error significantly. However, it would be interesting to study-at this micro level and with 
higher frequency data-the effect of financial development on the time-series of volatilities .

\subsection{Industrial data}

The industry data are taken from UNIDO's (2001) Indstat-3 dataset, which provides yearly observations (1963-1999) on production indexes for 28 ISIC-3 manufacturing segments in a large number of countries. The sample consists of 57,078 observations that correspond to 1,574 country-industry units spread over 59 countries. The actual number of industries varies by country. On average, each country has 26 industries, and in 32 countries there are data on all 28 industries. The sample period also varies by country and industry, although each country-industry unit has at least 26 years of continuous data. The UNIDO database reports information for more than 100 countries, but for a large number of these there are data on only a few industries or a few years. This last issue is particularly important since the time-series dimension is necessary for computing reliable estimates of volatility. Also, for many countries there is no information on GDP or financial development, reducing the final sample to 59 countries. The data on country GDP (in constant local-currency units) are taken from the World Bank data set (2001). For a more detailed description of the data, see the appendix. Firm-level data are explained in Section 6.

\subsection{Frequency of fluctuations}

Economic time series, like industrial output, trend upward. In order to compute standard deviations and correlations, it is necessary to remove the underlying trend. One way to do this is by using log changes (growth rates). Another detrending method is use of the Baxter and King (1999) (BK) filter, commonly used in the business cycle literature. For the purposes of this paper, the choice of detrending method has little or no impact on the results. ${ }^{5}$

\footnotetext{
${ }^{5}$ The weights of the BK filter can be found in Table 4 of Baxter and King (1999). The filter involves dropping the first three and the last three years of each series. Another popular filter is
} 
Detrending allows us to concentrate on short- and medium-term fluctuations and consequently on how financial markets enable firms to smooth transitory shocks. Detrending can eliminate a long-run shock, such as a permanent fall in demand and hence in profitability; for example, the demand curve for wood shifted to the left when substitutes like plastic and metal in the manufacture of furniture were introduced. Very short-term fluctuations like seasonal effects-for example, a spike in demand due to the sale of Christmas trees-are ignored since it is impossible to identify such short-term effects with annual data.

\subsection{Measures of financial development}

The basic measure of financial development used in this paper is the ratio of average private credit issued by depository institutions to GDP, taken from Beck, Demirgüç-Kunt and Levine (1999). Private credit is a standard measure of financial depth, and it is of particular interest, given the role of banks in pooling and smoothing shocks. Credit issued by a central bank, or credit issued to the government or public firms is not included. A second measure, from the same data set, is what is here called total capitalization over GDP. Total capitalization includes bank credit, credit by other financial institutions, and stock market capitalization. The correlation between total capitalization and private credit is 0.85 . Alternative measures of financial depth are all highly correlated with these two measures.

In order to alleviate endogeneity issues, financial development is instrumented using legal and institutional variables, which are arguably predetermined. The instruments consist of dummy variables representing the legal origin of the country, taken from La Porta et al. (1998); the rule of law index developed by Kaufmann, Kraay, and Mastruzzi (2003); ${ }^{6}$ and the corruption index from the International Country Risk

the one designed by Hodrick and Prescott (1997) (HP). In practical terms, there is little difference between the HP filter and the BK filter, although the BK filter solves some of the problems present in the HP filter.

${ }^{6}$ The average of the years reported is used. 
Guide. ${ }^{7}$ The rules of law and corruption capture the stability and efficiency of the legal system and are important complements to legal origin in explaining cross-country variation in financial development. The $\mathrm{R}^{2}$ of the regression of private credit on this set of variables is 50 percent ( 25 percent if legal origin is the only explanatory variable).

The sample averages of financial development for each country are used, thereby ignoring changes in financial development over time. This should not be a major concern since all countries tend to increase financial development together, so that the ranking in terms of financial development does not change dramatically during the sample period.

\subsection{Financial dependence at the industry level}

A requisite for testing the differential impact of financial development across industries is a measure of the availability of internal funds at the industry level-in other words, a proxy for $W$ in the model. The index of external financial dependence from Rajan and Zingales (RZ, 1998) measures the gap between investment and cash flows inherent to each industry. The index is defined as capital expenditures minus cash flow from operations divided by capital expenditures, aggregating U.S.-based, publicly listed firms into industries for the 1970s and 1980s. (The average of these two indexes is used.) Since RZ average capital expenditures and cash flows over time and across firms (mature and young), their index is a good approximation of the average net reinvestment need in an industry and not just of dependence at the initial stage of a project. This last point is important since the concept to measure is the relative dependence of an industry when hit by a transitory shock, not when planning a longterm expansion. Note that the relevant measure is the need for funds net of internal funds available; a pure measure of need for funds does not necessarily indicate the degree of dependence on external financing.

\footnotetext{
7 The corruption average reported by La Porta et al. (1998) is used. For those countries with missing values in La Porta et al. (1998), values are taken from the ICRG issue of April 2002 (Table 3B).
} 
RZ assume that there are technological reasons why some industries rely more on external funds than others. For example, industries need more external funds if they typically operate on a large scale, with high levels of working capital, high R\&D, or long cash-harvest periods. Industries that meet these criteria and have a high external dependence include plastic products, machinery, and professional equipment. Industries with low external dependence include food, footwear, and clothing. Also, since dependence on external finance is measured in the United States, a country with a developed financial market (probably the closest to a first-best or a flat-credit supply), it is argued that the index captures technological differences among industries in their demand for credit.

Assuming that these technological differences persist across countries, the external dependence of industries in the United States can be used to rank industries in every country. Identification does not require that industries have exactly the same external dependence level in every country, only that the rankings among them remain stable. One might think that industries with more difficulties in coping with shocks hold larger buffer stocks of cash as a precaution in poorly developed financial markets. However, the assumption here is that this type of response cannot completely offset the technological differences among industries identified by RZ. Moreover, Holmstrom and Tirole (1998) show that liquidity hoarding is affected by financial constraints; this implies that an industry also faces credit rationing when trying to secure funds as a precaution for future needs.

A pitfall of the RZ index is that an industry cannot be dependent forever: At some point firms have to repay investors. ${ }^{8}$ The real question, then, is: For how long can an industry be dependent without violating its long-run budget constraint? In other words, how rapid is the progress of the financial life cycle of an industry from net borrower to net payer? If it is relatively slow, considering external dependence as fixed throughout the sample period is not a bad approximation. The high correlation of external dependence in the 1970s with external dependence in the 1980s (0.63) gives 
evidence in support of a relatively slow life cycle at the industry (not necessarily at the firm) level.

The purpose of the RZ index is to find a source of variation in the financial needs of industries that is independent of their current investment opportunities. An exogenous, that is, technology-driven, variable is desirable to get around the endogeneity issues that affect many of the tests involving financial constraints. Obviously, the gains in terms of exogeneity come with some costs (or assumptions), as just mentioned.

\section{Financial development reduces industrial volatility}

\subsection{Basic results}

Table 1 shows the results from estimating equation (4) by regression analysis. The industries are split into two groups-high and low financial dependence-and then the regression is run for each sub-sample. Results are shown for two detrending methods for computing volatility (panels A and B).

Financial development reduces volatility in both groups of industries in a significant way. The levels of economic development (represented by per capita GDP) and government size also reduce volatility. Interestingly, the trade openness of a country increases industrial volatility in the same way in both groups of industries.

The result that financial development reduces volatility on average does not rule out the possibility that during short periods of time we may be able to observe higher volatility in more-developed financial systems. For instance, a more-developed system allows firms to adjust rapidly to a positive shock to investment opportunities, while in a poorly developed system it takes longer for firms to adjust. The results in Table 1 suggest that, over the last four decades, periods of higher volatility in better financial system are simply not the rule.

\footnotetext{
8 The author thanks John Campbell for pointing out this budget constraint logic.
} 
If financial development reduces volatility, we can expect the effect to be stronger in highly dependent industries. In fact, the effect of financial development is approximately 50 percent greater in the high-dependence group than in the lowdependence group. Note that the difference between coefficients of the other-country controls is never significant at a reasonable confidence level (below 10 percent).

The shortcoming of the approach reported in Table 1 is that financial development may be correlated with unobservable country variables that explain the reduction in volatility. The specification in equation (5) controls for this possibility by including country fixed effects and by focusing only on the differential effect of financial development over industries of high and low external financial dependence $\left(\beta_{1}\right)$. In cases in which financial development reduces output volatility, we expect a negative coefficient on the interaction between financial development and financial dependence.

Table 2 shows the results of regression estimation of equation (5). Two measures of financial development are used: private credit and total capitalization, and results are also presented in which the legal variables are used as instruments. ${ }^{9}$ The coefficients show that financial development reduces volatility particularly among industries with high financial dependence. The estimates are always statistically significant at the 5 percent level, except for those shown in column 5. Interestingly, the coefficients with total capitalization are all smaller in magnitude than those with private credit. In other words, a 1 percent increase in private credit has a larger impact on volatility than a 1 percent increase in total capitalization, suggesting that bank credit is the main channel through which production risks are smoothed.

An easier way to see how these estimates differ is by looking at the last row of Table 2. This row shows the effect of a 50-percentage-point increase in the corresponding measure of financial development on the highly dependent versus the less-dependent industries-or on an industry in the 90th percentile versus an industry in the 10th percentile of the RZ index, in the case of the continuous measure of financial

\footnotetext{
${ }^{9}$ More precisely, the interaction of financial development and financial dependence is instrumented by the interactions of legal variables and financial dependence.
} 
dependence. ${ }^{10}$ The effect is reported as a percentage of the median industrial volatility in the sample. For instance, when using private credit as the measure of financial development, the results imply that a highly dependent industry reduces its standard deviation by approximately 7 percent to 13 percent more than a less-dependent industry.

\subsection{Focusing on the interaction approach}

The results in Table 2 are powerful since any country characteristic is controlled for by using the country fixed effects. The implications of the model are also tested at the level of second derivatives, by examining the differential effect of financial development on industries sorted by their financial dependence. The possibility still exists, however, that the interaction of financial development with financial dependence may be depicting a pattern produced by other combinations of country and industry characteristics. The reduction in volatility may be achieved by nonfinancial arrangements or the pattern of shocks may change in a way that results in lower volatility. In the first instance, effects to consider include the possibility that government transfers may favor more highly dependent industries and the possibility that a country's openness may smooth shocks by enabling access to a larger market or better technologies. In the second instance, a possibility to consider is that economic development, which is highly correlated with financial development, changes the structure of shocks affecting particular industries, such as those producing durables or those using a more capital-intensive technology.

If government transfers or subsidies favor financially dependent industries, highly dependent industries should benefit more from higher government expenditures. This channel can be insignificant in a country like the United States, but may be important in countries where the government sector is relatively large, such as the

\footnotetext{
${ }^{10}$ A 50-percentage-point increase is comparable to the difference in private credit over GDP between Ecuador (14 percent) and Singapore (64 percent), or the difference in total capitalization over GDP between Austria (74 percent) and the United Kingdom (124 percent)
} 
Netherlands or Sweden. In order to test this, we can include in equation (5) the interaction of financial dependence and government expenditures as percentage of GDP. ${ }^{11}$ The results, displayed in the first panel of Table 3, show that this channel does not exist, and the interaction of financial dependence and external dependence is robust to the inclusion of the new variable. It is important to remember that the measure of financial development-private credit-does not include credit extended to public enterprises, so the results cannot be explained by that possibility either.

In theory, trade openness can also dampen volatility, although this seems at odds with the results in Table 1. Trade can smooth shocks in two ways: First, swings in domestic demand are less important once industries have access to foreign markets, and second, better and less-expensive technologies are easily shared with the rest of the world. When the interaction of trade openness with external dependence is tested, we find that the interaction does not cancel the effect of financial development. We test the interaction of the openness index with a measure of tradability for each industry. (See the appendix for a description of this and other variables.) The new interaction term has a positive (but not significant) effect on volatility, probably indicating that tradable goods producers are exposed to global shocks in an open economy. In any case, the interaction of financial development with external finance is significant in every regression, and the coefficients are sufficiently stable to show that trade is not a relevant omitted variable.

As financial development increases, the structure of shocks (for instance, the amplitude of cash-flow and investment-opportunity shocks) can also change. In theory, shocks can change in such a way that highly dependent industries are technologically less volatile in countries that have a high level of financial development; if this is the case, the effects that we see are not the product of looser financial constraints, but of lessfrequent and smaller shocks.

${ }^{11}$ The data used are average government expenditures as percentage of GDP from the International Monetary Fund (Government Financial Statistics). 
The real challenge to this alternative view is to explain why the structure of shocks changes coincidentally with financial development in a way that matches the cross-industry pattern of external finance dependence. The next step is to test some possibilities.

Economic development is the main candidate for a hidden variable that is correlated with financial development and that can affect the structure of shocks. The interaction of economic development (measured by the log of per capita GDP) with high financial dependence is tested first. As shown in the first panel of Table 3, there is no differential impact beyond that associated with financial development. ${ }^{12}$

It is still possible that economic development affects industries differentially, according to other characteristics that are correlated with financial dependence. In the case of durable and investment goods, it may be that, as countries get richer, industries producing these goods benefit from better technologies for managing inventories or from more stable demand (due, for example, to more-developed secondary markets for these products). Capital-intensive industries probably benefit from having a greater abundance of physical capital that can be substituted for other inputs when hit by a shock; that is, instead of practicing costly labor hoarding, these producers can substitute capital for labor more easily when hit by a shock. The same can be argued about industries that are intensive in their use of oil, another common source of shocks. These possibilities are tested in the lower panel of Table 3. The interactions of GDP with capital-intensive and oil-intensive industries are not significant. The interactions with durable goods and with investment goods are significant, and they have the expected negative signs. Nevertheless, the interaction of financial development with external dependence remains significant at the 10 percent level. The coefficient of the interaction is reduced, but it is still within two standard errors of the baseline case. These are tough

\footnotetext{
${ }^{12}$ One practical reason for using the dummy of high financial dependence is that the correlation with the other variables included in Table 3 is very high if one uses the continuous measure of dependence. Interactions tend not to be significant despite the fact that when they are included alone they are significant. Use of the dummy variable alleviates the possible multicolinearity.
} 
control variables, so it is reassuring that the basic interaction survives the inclusion of these controls.

The next step is to try to separate the effect of financial dependence from the effects of the other industry variables by computing a measure of dependence that is not correlated with these industry variables. The orthogonal external dependence is the residual of the regression of financial dependence on durable goods, investment goods, capital intensity, and tradable goods producers. ${ }^{13}$ When the interaction of financial development with the orthogonal external dependence is included, the results are virtually unchanged, in terms of both statistical significance and magnitude.

A final step is to include as a right-hand-side control the average size of each industry in each country (Table 3, first column). Smaller industries are more volatile, as can be expected. Despite the fact that the coefficient is reduced almost in half, it is hard to argue that size is an exogenous variable that can mechanically account for the results. As RZ (1998) show, industry size is affected by financial development and financial dependence, and therefore it is determined simultaneously with the volatility of output.

Overall, the reduction in volatility is a robust finding. The next section explores the composition of this volatility reduction.

\section{Anatomy of the volatility reduction}

\subsection{Systematic and idiosyncratic volatility}

Volatility is divided into two components according to whether the fluctuation is specific to an industry in a given country or affects the whole country. The volatility that is correlated with fluctuations in a country's GDP is called systematic, and the volatility that is uncorrelated (by construction) with GDP is called idiosyncratic. The finding is that, even though both volatilities fall with financial development, idiosyncratic volatility declines more steeply. 
Suppose the following factor model describes the fluctuations of industrial production: ${ }^{14}$

$\Delta y_{i, c, t}=\beta_{i, c} \Delta g d p_{c, t}+\varepsilon_{i, c, t}$.

$\Delta y_{i, c, t}$ is the cyclical production of industry $i$ in country $c$ at time $t ; \Delta g d p_{c, t}$ is the cyclical fluctuation of aggregate GDP; and $\varepsilon_{i, c, t}$ is an idiosyncratic shock, orthogonal to aggregate GDP fluctuations. $\beta_{i, c}$ represents the sensitivity of the industry to aggregate fluctuations, and it is a function of industry and country characteristics; for example, those industries that produce durable goods usually have a higher $\beta_{\mathrm{i}, \mathrm{c}}$ than industries producing nondurables.

$\Delta g d p_{c, t}$ and $\varepsilon_{i, c, t}$ have standard deviations of $\sigma_{g d p, c}$ and $\sigma_{\varepsilon, i c}$, respectively, so the total variance of output is

$$
\sigma_{i c}^{2}=\beta_{i c}^{2} \sigma_{g d p, c}^{2}+\sigma_{\varepsilon, i c}^{2} \text {. }
$$

The first term in the right-hand side of (7) is the systematic variance, and the second is the idiosyncratic variance. Both components can be estimated by running OLS regressions of equation (6) and computing the volatility of fitted values and residuals. Table 4 presents the summary of the variance decomposition.

Systematic variance represents between 10 percent and 20 percent of industrial volatility. When comparing countries with low and high levels of private credit, we see that, despite the overall drop in volatility for countries with high levels of private credit, there is an increase in the shares attributable to systematic volatility. The source of this change is a more pronounced reduction of idiosyncratic volatility, 67 percent, compared with a 36 percent reduction in systematic volatility. The reduction in systematic volatility reported here is also consistent with the credit channel literature and with the empirical evidence of Braun and Larrain (2004).

\footnotetext{
${ }^{13}$ The $\mathrm{R}^{2}$ of this regression is 22 percent. The correlation of external dependence with orthogonal external dependence is 0.88 .

${ }^{14}$ Since with the data are de-trended, the intercept of this regression is negligible.
} 
Figure 1 shows systematic and idiosyncratic volatility as percent of total volatility for several countries ordered (from left to right) by the ratio of their level of private credit to GDP. Note that in developed countries like the United States and the United Kingdom, systematic volatility accounts for 40 percent or more of industrial volatility, while in countries like Nigeria and Paraguay, it is less than 10 percent.

The correlation coefficient between industrial production and GDP measures the share of total volatility that corresponds to systematic volatility. One can also think of the square correlation as the $R^{2}$ of the regression estimate of equation (6):

$$
\operatorname{Corr}\left(\Delta y_{i, c, t}, \Delta g d p_{c, t}\right)^{2}=\beta_{i c}^{2} \sigma_{g d p, c}^{2} /\left[\beta_{i c}^{2} \sigma_{g d p, c}^{2}+\sigma_{\varepsilon, i c}^{2}\right]
$$

Table 4 suggests that the correlations increase with financial development, which is equivalent to saying that systematic volatility accounts for a higher percentage of total volatility in more financially developed countries. As also seen in Table 4, this change in composition is achieved by an increasing reduction in idiosyncratic volatility in the more-financially-developed countries, rather than by an absolute increase in systematic volatility. This is not the result of larger measurement error in underdeveloped countries, since the cross-industry pattern in volatility reduction is again present. When equation (5) is estimated separately to test for systematic and idiosyncratic volatility, the results (not reported) show that financial development disproportionately reduces both types of volatility in more financially dependent industries.

\subsection{Regressions with correlations as the dependent variables}

Next, the basic regressions are repeated, using the correlation instead of the standard deviation as the dependent variable. The regressions show the effect of financial development on the composition of volatility measured with the correlation. A positive coefficient of financial development means that financial development increases the systematic share of volatility. The conjecture is again that if there is a change in the composition of volatility induced by financial development, the change is stronger 
among those industries that are more financially dependent. This is not explicitly derived from the model presented in Section 2, but it is still a way of checking the robustness of the finding by controlling for unobservable country characteristics.

Table 5, shows the effect of financial development on industry correlations with GDP in different sub-samples. Panels A and B show that the correlations increase with financial development for both groups of industries, and that the effect is stronger for highly dependent industries. The results are statistically significant for the industries with high financial dependence but not for the group with low financial dependence. More importantly, the effect in the highly dependent group is statistically larger than that in the low-dependence group, although only when using BK-filtered data. ${ }^{15}$ Note that trade openness is highly significant in every regression and that it reduces correlations of industries with GDP.

The differential effect of financial development over industries is explored by running regression analysis of equation (5) with correlations as the dependent variable. As seen in the last row of Table 6, correlations of highly dependent industries increase by 9 percent more than those of the less-dependent industries when private credit increases by 50 percentage points of GDP (in the cross-section of countries). Again, the effect of financial development is larger when measured by private credit than when measured by total capitalization, suggesting a special role for banks in producing the change in the composition of volatility.

Table 7 presents several robustness checks. First, since financial development allows a higher degree of specialization in financially dependent industries (Rajan and Zingales 1998), the higher correlations could be driven mechanically by size instead of by reductions in volatility. Basically, an industry is more correlated with GDP when it represents a larger share of it, independent of its volatility. (Note that we have already

${ }^{15}$ According to Baxter and King (1999), log-changes are particularly problematic when measuring the synchronization between time series, so we should pay more attention to the results with the BK filter. Since correlations are bounded between -1 and 1, a logistic transformation was applied before the regressions were run, yielding basically the same results as those reported here. Moreover, none of the fitted values in the reported regressions lies outside the $[-1,1]$ interval. 
shown that volatilities are reduced; but consider for a moment correlations without the finding of the volatility reduction.) One problem with this idea is that an industry represents on average less than 2 percent of manufacturing value added, and manufacturing itself represents about 20 percent of GDP in industrialized countries, so the increment in size for the average industry is negligible in terms of its effect on the correlation with total GDP. In any case, the level of specialization is controlled for by including the relative size of each industry in each country, computed as the average ratio of value added to the country's total manufacturing value added. As seen in Table 7 , the coefficient of the interaction is still significant, although smaller than the coefficients in the other specifications. Size is significant, although it is hard to infer causality because of the simultaneity of effects.

If industries depend on government subsidies, it may be the case that in countries with a sizable government sector, correlations with GDP are higher as a result of cyclical variation in tax receipts, but there is no evidence supporting this story. Openness to trade exposes the country to external shocks, and, as seen in Table 7, this is a source of reduced co-movement between financially dependent industries and a country's GDP. In any case, the interaction of financial development and external dependence is still significant at the 1 percent level.

Another set of alternative explanations is that economic development (represented by per capita GDP) increases the exposure of a group of industries to particular sources of aggregate shocks that produce the relative increase in systematic volatility. As seen in the second column of Table 7, the interaction of per capita GDP with financial dependence renders insignificant the interaction with financial development, although the high correlation of per capita GDP with financial development makes this difficult to interpret. An attempt is made to test more direct mechanisms of how economic development can affect correlations by including interactions with other industry characteristics. For example, economic development can change the productive structure of a country in a way that increases the exposure to oil shocks. If this is the case, then oil-intensive industries (those industries that use more 
oil in their productive processes) should have higher correlations with GDP. The second panel in Table 7 shows that there is no evidence for this. More generally, economic development can affect industries grouped by other characteristics. For example, for industries producing durable or investment goods, empirical results show that this channel may be operating, although it is hard to rule out the influence of finance, since purchases of durable goods and investment goods are usually financed with credit. For those industries that use capital-intensive technology, the effect-if any-is to decrease the exposure to systematic risk. In terms of significance, the interaction of financial development and external dependence survives the inclusion of all these interactions of industry characteristics with economic development, although in some cases magnitude is somewhat reduced. Finally, once we include the interaction of financial development with orthogonal external dependence, the results are almost intact.

\subsection{Discussion and caveats about the variance decomposition}

The results of the variance decomposition should be interpreted as evidence that financial constraints are harder to relax in the case of aggregate shocks. If financial systems pool and subdivide risks among many agents, so that each receives only a small part of the original shock, it seems natural that aggregate shocks will be more difficult to smooth (there will be less room for subdividing or diversification). Therefore, financial markets and intermediaries will be able to reduce idiosyncratic volatility to a larger extent than systematic volatility. ${ }^{16}$

The empirical measure of aggregate shocks has to match the extension of the financial system under consideration. Since financial development is measured at the country level, aggregate shocks are defined at the country level as well. Arguably, these are not truly aggregate shocks (as compared with worldwide shocks). International

\footnotetext{
${ }^{16}$ Models of production and financial constraints do not often make the distinction between aggregate and idiosyncratic shocks. For instance, Bernanke and Gertler (1989) assume that there are always enough savings to finance the entire investment plan of the productive sector; therefore, there is no aggregate shortage of funds, and the interest rate is constant. A notable exception is Holmstrom and Tirole (1998).
} 
borrowing-which has been ignored so far-can bias the results, although it is not clear in which direction. For instance, the availability of foreign credit can help firms smooth country shocks and idiosyncratic shocks at the same time, but it is hard to say whether foreign creditors are more likely to lend, or to lend more, in one case than in the other. If anything, it may be harder to get credit in the case of a countrywide shock because international lending is subject to many of the same contracting problems as domestic lending as well as to other difficulties such as the lack of collateral subject to appropriation if circumstances warrant. Moreover, if domestic financial development is a prerequisite or complement to international financial integration (and not a substitute), the availability of foreign credit does not introduce a major bias. ${ }^{17}$

The presence of multinationals and conglomerates has also been ignored, but it is again not clear how this could bias the results. For instance, if multinationals are more prevalent than stand-alone firms in poorly developed countries, then they should allow their local branches to smooth shocks, particularly the idiosyncratic shocks, producing a bias against the results found here. The fact that the result is consistent across countries

and industries shows that it is a robust finding, not easily explained by these alternative hypotheses.

\section{Exploring the mechanism with firm-level data}

The model in Section 2 is mainly about the volatility of output, although the behavior of credit is intimately related to output. It is shown that volatility is reduced on average by financial development, and according to the model this is to be expected when financial development enables firms to increase their borrowing during times of low cash flows and output. Countercyclical borrowing is therefore central to the mechanism that explains the reduction in output volatility. We expect financial

\footnotetext{
${ }^{17}$ For more on the issue of international financial integration and domestic financial development, see Caballero and Krishnamurthy (2001). See also Guiso, Sapienza, and Zingales
} 
development to increase the countercyclicality of borrowing in the sense of reducing its correlation with output or making the correlation more negative. If financial development reduces the volatility of output, it is by disassociating borrowing from the availability of internal funds-in other words, by breaking the association of low cash flows with low output whenever investment opportunities are not worsening. Firmlevel balance sheet data are used to explore this mechanism, since no industry-level financial data are available.

\subsection{Measurement}

The firm-level data are from Compustat Global Industrial/Commercial. This data set provides annual balance sheet information on firms from all over the world for the years 1991-2002. The sample is restricted to those firms in manufacturing sectors that match our industry data and that cover the same 59 countries as our industry data. Only firms with five or more years of data are considered since the tests require timeseries variation. With these restrictions, the remaining data set consists of almost 47,000 observations that correspond to 5,651 firms in 42 countries. The average number of years of data per firm is eight. ${ }^{18}$

Since no production index or value-added information exists at the firm level, output (or the level of activity) is measured by sales. Short-term debt is used to represent borrowing. The measure of short-term debt includes notes payable and accounts payable (trade credit and other instruments), but excludes long-term debt due in one year, accrued expenses, taxes payable, and proposed dividends. ${ }^{19}$ To control for

(2004) who show that local financial development cannot be completely substituted by financial integration.

${ }^{18}$ Data series with missing values for assets or debt plus equity, with assets not equal to debt plus equity, or with negative equity are eliminated. These represent only minor adjustments.

${ }^{19}$ Notes payable alone is arguably a better measure of short-term borrowing, but data on this category are scarce. More than 25 percent of the firm-year observations are zero in notes payable, indicating either that most of these items are subsumed in accounts payable (what Compustat does when both are reported together in the firm's balance sheet) or that firms do not have access to the instruments in this category. The first explanation seems more plausible since firms in the sample are usually large and should have access to most financial instruments. The line items 
mergers and growth due to inflation, two ratios are used: sales to assets and short-term debt to assets. Finally, since the theory speaks of fluctuations rather than levels, the log differences of these ratios are used, that is, $\Delta \log$ (sales/assets) and $\Delta \log$ (short-term debt/assets), respectively.

\subsection{Volatility of sales and the covariance with short-term debt}

Cross-country and cross-industry implications on sales and short-term debt are tested using the basic regression augmented to control for firm characteristics:

St. deviation ${ }_{i, c, f}=\alpha_{1}$ Financial development $_{c}+\alpha_{2}$ Country controls $_{c}+\alpha_{3}$ Industry dummies $_{i}+\alpha_{4}$

$$
\text { Firm controls } s_{i, c, f}+\varepsilon_{i, c, f}
$$

Equation (8) is estimated for three different variables: the standard deviation of $\Delta \log ($ sales/assets) and the covariance and correlation between $\Delta \log$ (sales/assets) and $\Delta \log ($ short-term debt/assets), which measure co-movement. The subscript $f$ refers to a firm, the unit of observation. Also included, in addition to the country controls and industry fixed effects (at the ISIC3 level), are three firm controls that are usually correlated with leverage (See Rajan and Zingales 1995): the log of sales as a proxy for size, profitability defined as EBITDA (earnings before interest, taxes, depreciation, and amortization) over assets, and tangibility defined as tangible assets over total assets. For each firm, the time average of these variables is used.

Results are displayed in Table 8. In terms of sales volatility, the dampening effect of financial development is confirmed. Note the weak effect of per capita GDP and other country variables in the regression, suggesting that financial development is, in fact, the main channel through which sales are smoothed. The firm variables are all statistically significant with the expected signs: Firms that are bigger, more profitable, and that produce more-tangible output have lower sales volatility. The difference

from Compustat Global used are: sales (data 1), notes payable (data 96), accounts payable (data 97 and data 101), and total assets (data 89). 
between more and less financially dependent industries is not significant at conventional levels in this case.

As was clear in the model, the volatility of debt per se does not say much about the exact mechanism through which financial development operates. Moreover, results (not reported) show that the volatility of debt decreases with financial development instead of increasing according to the model. But this somewhat negative result is to be expected for two reasons. First, our measure of short-term debt includes trade credit, which is intimately related to sales; and this feedback may obscure the effect of financial development that we are seeking. Since sales volatility is reduced by financial development, trade-credit volatility is also reduced on average, driving down the volatility of short-term debt. Second, substitution of short-term debt for other sources of credit or hedging goes hand-in-hand with development, implying that the extra volatility may be seen in other accounts. In this regard, Demirgüç-Kunt and Maksimovic (1999) present evidence that firms in more-developed financial systems have proportionally less short-term debt.

Instead, the co-movement of debt and output is decisive in distinguishing between two possible explanations about financial development and volatility. As seen in columns 3 and 4 in Table 8, financial development reduces the covariance of sales and debt-in other words, in financially developed countries borrowing co-varies more negatively with output. This can be interpreted as showing that the reduction in sales volatility is achieved by borrowing more when sales are down (and repaying when sales are up). The reduction in covariance is observed mostly among firms in financially dependent industries, which is what we would expect. In fact, financial development is significant only in this group as an explanatory variable.

The results with the correlations in columns 5 and 6 are in line with the results from the covariance and are even stronger. The correlation is a scaled covariance and is therefore independent of the volatilities of sales and debt and immune to the problems with the volatility of debt mentioned above. As a pure measure of co-movement, the correlation results say not only that debt and sales move more strongly in different 
directions in more financially developed countries than in less financially developed countries, but also that they do so more frequently. This is equivalent to saying that in financially developed countries borrowing is more countercyclical. Again, this result is present especially among the financially dependent industries, now with a difference that is statistically significant at the 1 percent level with respect to the other industries.

One notable thing about Table 8 is that economic development (proxied by per capita GDP) significantly increases the covariance and correlation of sales and debt. The fact that it has the opposite effect from that of financial development supports the idea that both the concepts and the mechanisms operating are distinct. These results, and all results in Table 8, are robust to considering only the subsample of non-U.S. firms.

Firm-level evidence supports the idea that better financial systems not only provide more credit to enable faster growth, but also provide more credit when it is needed to smooth cash-flow shocks. The results are consistent with the previous industry evidence; nevertheless, they should be taken with caution because of data limitations. First, higher frequency data or longer time-series would be required in order to compute volatilities and covariances that are less noisy. Second, knowing more about the composition of short-term debt is necessary to derive definite conclusions.

\section{Conclusions}

Three main findings are reported in this paper. First, financial development reduces industrial volatility. Second, the reduction in production volatility comes mainly from a reduction in idiosyncratic volatility. As a corollary of this point, the correlations of industry output with GDP increase with financial development. Third, at the firm level, short-term debt is more negatively correlated with firm activity as financial development increases, suggesting that debt serves to smooth output.

This paper contributes primarily to the literature on financial constraints and to the ongoing debate about the impact of financial development on real activity. The main message is that a well-developed financial system is necessary to insure a stable productive sector. The results can also be interpreted as showing that banks (the main 
measure of financial development used in the paper) smooth shocks that affect the productive sector.

A final interesting issue concerns the implications of these findings for the behavior of stock markets. Morck, Yeung, and Yu (2000) show that stocks in less developed countries tend to have more synchronized movements than stocks in more developed countries-in other words, the correlation of a particular stock with the market is higher in a less developed country. This paper shows that exactly the opposite pattern is true in terms of output correlations with GDP-a result that may appear somewhat puzzling. Reconciling and understanding both results is an important area for future research. For example, a relevant issue is sample selection: The industry data used include more firms than those listed in the local stock market, and the characteristics of the listed firms may explain why the correlations in output and stock prices diverge. Also, the paper's findings relate to short-run fluctuations, while the stock market reflects the long-run prospects of firms. If stock markets understand the idiosyncratic nature of most fluctuations in less financially developed countries, it may be possible to observe higher correlations among stocks in those countries, assuming long-run fundamentals are more correlated (because of macro risk, for instance). Morck, Yeung, and $\mathrm{Yu}$ argue that their results show the poor efficiency of stock markets in developing countries; at this point, the results in this paper do not necessarily support or contradict that hypothesis. In any case, the interplay between the real economy (cash flows, output) and stock markets in an environment of financial underdevelopment deserves more study. 


\section{References}

1. Acemoglu, D., S. Johnson, J. Robinson, and Y. Thaicharoen. 2003. "Institutional Causes, Macroeconomic Symptoms: Volatility, Crises and Growth." Journal of Monetary Economics 50(1) January: 49-123.

2. Baxter, M., and R. G. King. 1999. "Measuring Business Cycles: Approximate Band-Pass Filters for Economic Time Series." Review of Economics and Statistics 81(4) November: 575-593.

3. Beck, T., A. Demirgüç-Kunt, and R. Levine. 1999. "A New Database on Financial Development and Structure." World Bank. Working Paper 2146. July.

4. Bernanke, B., and M. Gertler. 1989 "Agency Costs, Net Worth, and Business Fluctuations." American Economic Review 79(1) March: 14-31.

5. Blanchard, O., F. Lopez-de-Silanes, and A. Shleifer. 1994. "What do Firms do with Cash Windfalls?" Journal of Financial Economics 36(3) December: 337-360.

6. Braun, M. and B. Larrain. 2004. "Finance and the Business Cycle: International, Inter-Industry Evidence. forthcoming in The Journal of Finance.

7. Caballero, R., and A. Krishnamurthy. 2001. "International and Domestic Collateral Constraints in a Model of Emerging Market Crises." Journal of Monetary Economics 48(3) December: 513-548.

8. Demirgüç-Kunt, A., and V. Maksimovic. 1999, "Institutions, Financial Markets, and Firm Debt Maturity." Journal of Financial Economics 54(3) December: 295-336.

9. Frankel, J., and D. Romer. 1999. “Does Trade Cause Growth?” American Economic Review 89(3) June: 379-399.

10. Galindo, A., A. Micco, and G. Suárez. 2003. "Creditor Protection and the Cyclical Properties of Credit." mimeo Harvard University.

11. Guiso, L., P. Sapienza and L. Zingales. 2004. “Does Local Financial Development Matter?" forthcoming in the Quarterly Journal of Economics.

12. Hart, O., and J. Moore. 1994. "A Theory of Debt Based on the Inalienability of Human Capital." Quarterly Journal of Economics 109(4) November: 841-879.

13. Hodrick, R. and E. Prescott. 1997. "Postwar U.S. Business Cycles: An Empirical Investigation." Journal of Money, Credit, and Banking. 29(1) February: 1-16.

14. Holmstrom, B., and J. Tirole. 1998. "Private and Public Supply of Liquidity." Journal of Political Economy 106(1) February: 1-40.

15. Hubbard, R. 1998. “Capital-Market Imperfections and Investment." Journal of Economic Literature 36(1) March: 193-225. 
16. Kaplan, S., and L. Zingales. 1997. “Do Investment-Cash Flow Sensitivities Provide Useful Measures of Financing Constraints?" Quarterly Journal of Economics 112(1) February: 169-215.

17. Kaufmann, Kraay and Mastruzzi. 2003. “Governance Matters III: Governance Indicators for 1996-2002." www.worldbank/wbi/governance/govdata2002.

18. La Porta, R., F. Lopez-de-Silanes, A. Shleifer, and R. Vishny. 1998. "Law and Finance." Journal of Political Economy 106(6) December: 1113-1155.

19. Levine, R. 1997. “Financial Development and Growth: Views and Agenda." Journal of Economic Literature 35(2) June: 688-726.

20. Morck, R., B. Yeung, and W. Yu. 2000. “The Information Content of Stock Markets: Why Do Emerging Markets Have Synchronous Stock Price Movements?" Journal of Financial Economics 58(1-2) October-November: 215-260.

21. Myers, S., and N. Majluf. 1984. "Corporate Financing and Investment Decisions When Firms Have Information That Investors Do Not Have." Journal of Financial Economics 13(2) June: 187-221.

22. Raddatz, C. 2002. "Liquidity Needs and Vulnerability to Financial Underdevelopment." mimeo MIT.

23. Rajan, R.G., and L. Zingales. 1998. "Financial Dependence and Growth." American Economic Review 88(3) June: 559-586.

24. Rajan, R.G., and L. Zingales. 1995. “What Do We Know About Capital Structure? Some Evidence from International Data." The Journal of Finance 50(5) December: 1421-1460.

25. Stein, J. 2003. "Agency, Information and Corporate Investment." forthcoming in the Handbook of the Economics of Finance, edited by George Constantinides, Milton Harris, and Rene Stulz.

26. Townsend, R. 1979. "Optimal Contracts and Competitive Markets with Costly State Verification." Journal of Economic Theory 21(2) October: 265-293. 


\section{Appendix}

Durable Goods: Durable goods are assigned a 1, nondurable goods a 0 and semi-durable goods a 0.5 . We use the classification of durable and nondurable goods presented in BEA's Industry Accounts in the section of Gross Domestic Product by Industry (www.bea.gov/bea/dn2/gpo.htm). The industries described there are almost the same as the 28 industries we use. Since there is disagreement about the durability of some products, we create a semi-durable category. The semi-durable industries correspond basically to clothing, footwear and printing. For supporting evidence about the durability of these last items, see Table 2 in Bils and Klenow 1998 ("Using Consumer Theory to Test Competing Business Cycle Models." Journal of Political Economy, vol. 106, no.2). Books, for instance, are reported to have an expected life of 11 years, footwear approximately 2.5 years, and some clothing up to 4 years.

Investment Goods: The BEA provides information about the final uses of each commodity. This information, which is very close to industry output, especially when aggregated to the level of 28 industries, is contained in the use table of the Input-Output data section (www.bea.gov/bea/dn2.htm). We use the latest data available-data for 1998. For each industry, we consider the columns labeled as consumption and gross investment, either private or public, to construct the following measure: Investment/(Investment + Consumption). This measure captures the degree to which an industry tilts towards investment goods relative to consumption goods.

Tradable Goods: Using the BEA use tables, we construct the following measure of tradability of an industry: Trade/(Trade + Domestic Use), where trade is defined as exports plus imports, and domestic use is defined as consumption plus investment, either private or public. If this ratio is close to 1 , the industry is producing highly tradable goods, and conversely, if the ratio is close to 0 , the industry is producing goods that are not readily tradable.

Capital-intensive Technology: From the UNIDO database, Braun 2002 ("Financial Contractibility and Assets' Hardness: Industrial Composition and Growth," mimeo, Harvard University) computes the median gross fixed capital formation to value-added ratio in the U.S. between 1986 and 1995 for each industry.

Oil-intensive Technology: With the BEA use tables, we compute for each industry the ratio of input from industries 353 and 354 (oil related industries) to total input. Industries 353 and 354 are excluded from this variable. 


\section{Figure 1}

\section{Systematic and Idiosyncratic Variance}

This figure shows the share of the average industrial output variance that is systematic (dark gray) and idiosyncratic (light gray) in each country. Countries are shown in ascending order (from left to right) according to their level of private credit over GDP.

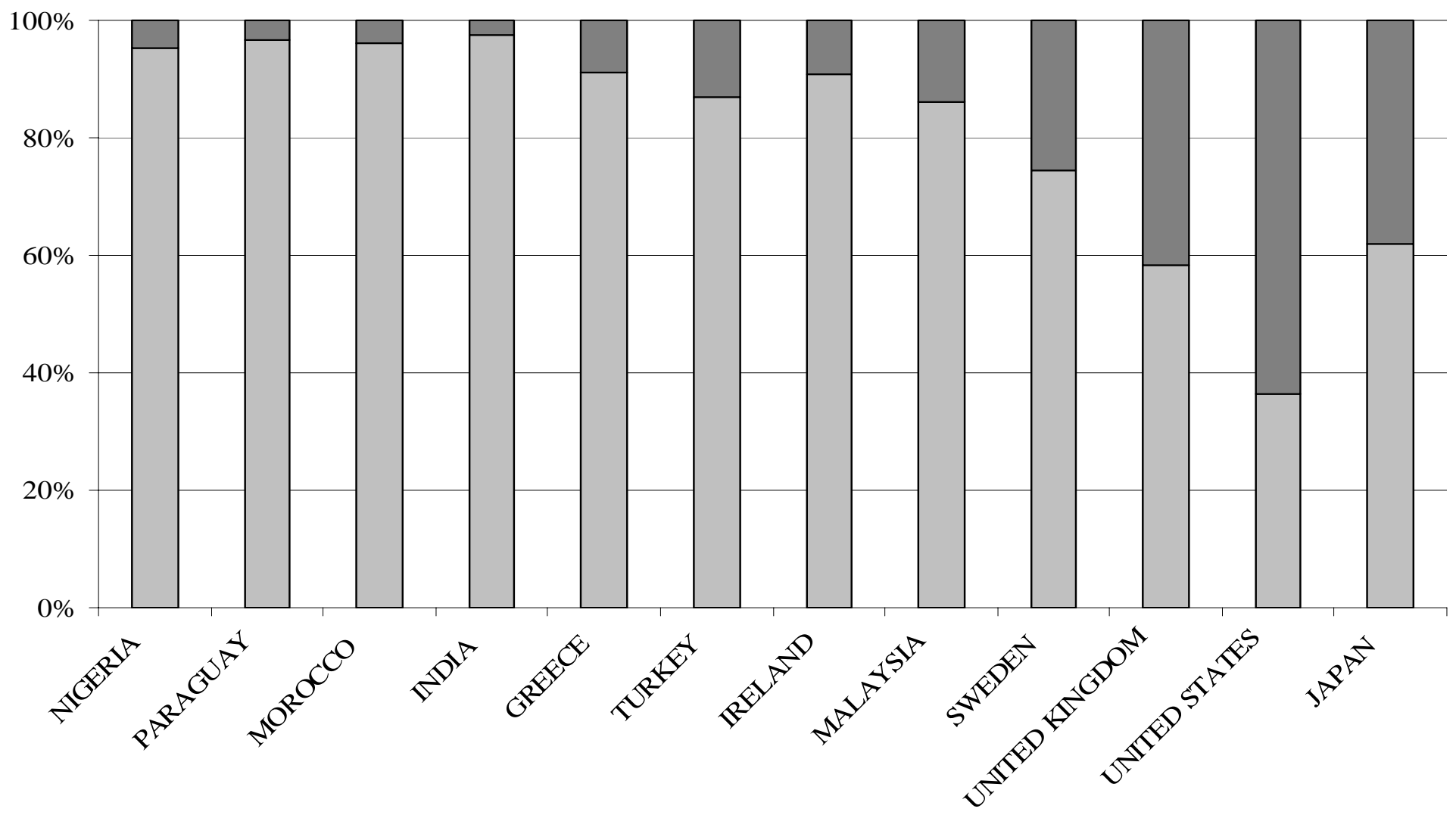




\section{TABLE 1}

\section{The Effect of Financial Development on Industrial Output Volatility}

specification: $\quad$ Std. deviation ${ }_{i, c}=\alpha_{1}$ Financial development $_{c}+\alpha_{2}$ Country controls $_{c}+\alpha_{3}$ Industry dummies $_{i}+\varepsilon_{i, c}$

Standard deviations of industrial output are computed using Baxter-King (BK) filtered data and log changes in panels A and B, respectively. The sample period is 1963 to 1999. Financial development is measured using average private credit over GDP of the country. The sample of industries is split in two according to whether they score above or below the median external-finance dependence. The third column in each panel shows the p-value of the test that the effect of financial development is stronger in industries with high financial dependence. This p-value is obtained from a regression that includes both groups of industries. Robust standard errors clustered by country are reported below the coefficients. Industry dummies are not reported. Significance (two-sided): $* 10 \%, * * 5 \%, * * * 1 \%$.

\begin{tabular}{|c|c|c|c|c|c|c|c|c|c|c|}
\hline \multirow[b]{3}{*}{ Independent Variables } & \multicolumn{5}{|c|}{$\begin{array}{c}\text { Panel A } \\
\text { Dep. Variable: St. Deviation (BK filter) }\end{array}$} & \multicolumn{5}{|c|}{$\begin{array}{c}\text { Panel B } \\
\text { Dep. Variable: St. Deviation (log changes) }\end{array}$} \\
\hline & \multicolumn{4}{|c|}{ Industry Subsample } & \multirow[b]{2}{*}{$\begin{array}{l}\text { p-value } \\
\text { High }<\text { Low }\end{array}$} & \multicolumn{4}{|c|}{ Industry Subsample } & \multirow[b]{2}{*}{$\begin{array}{c}\text { p-value } \\
\text { High }<\text { Low }\end{array}$} \\
\hline & $\begin{array}{c}\text { High } \\
\text { Financial } \\
\text { Dependence }\end{array}$ & & $\begin{array}{c}\text { Low } \\
\text { Financial } \\
\text { Dependence }\end{array}$ & & & $\begin{array}{c}\text { High } \\
\text { Financial } \\
\text { Dependence }\end{array}$ & & $\begin{array}{c}\text { Low } \\
\text { Financial } \\
\text { Dependenc }\end{array}$ & & \\
\hline Financial Development & $\begin{array}{c}-0.0457 \\
0.0172\end{array}$ & $* * *$ & $\begin{array}{c}-0.0325 \\
0.0159\end{array}$ & ** & $7 \%$ & $\begin{array}{c}-0.0761 \\
0.0286\end{array}$ & $* * *$ & $\begin{array}{c}-0.0471 \\
0.0284\end{array}$ & * & $3 \%$ \\
\hline Log Per Capita GDP & $\begin{array}{c}-0.0143 \\
0.0056\end{array}$ & ** & $\begin{array}{c}-0.0119 \\
0.0047\end{array}$ & ** & $23 \%$ & $\begin{array}{c}-0.0253 \\
0.0094\end{array}$ & $* * *$ & $\begin{array}{l}-0.0196 \\
0.0086\end{array}$ & $* *$ & $11 \%$ \\
\hline Trade Openness & $\begin{array}{c}0.0173 \\
0.0057\end{array}$ & $* * *$ & $\begin{array}{c}0.0167 \\
0.0039\end{array}$ & $* * *$ & $41 \%$ & $\begin{array}{c}0.0310 \\
0.0090\end{array}$ & $* * *$ & $\begin{array}{c}0.0310 \\
0.0074\end{array}$ & $* * *$ & $49 \%$ \\
\hline Government Expenditure & $\begin{array}{c}-0.0009 \\
0.0003\end{array}$ & $* * *$ & $\begin{array}{c}-0.0007 \\
0.0002\end{array}$ & $* * *$ & $13 \%$ & $\begin{array}{c}-0.0015 \\
0.0004\end{array}$ & $* * *$ & $\begin{array}{c}-0.0013 \\
0.0004\end{array}$ & $* * *$ & $25 \%$ \\
\hline Adjusted $\mathrm{R}^{2}$ & 0.326 & & 0.220 & & & 0.361 & & 0.243 & & \\
\hline
\end{tabular}




\section{TABLE 2}

\section{The Differential Effect of Financial Development over Industrial Output Volatility}

specification: $\quad$ Std. deviation ${ }_{i, c}=\beta_{1}$ (Financial development $_{c} *$ Financial dependence $\left._{i}\right)+\beta_{2}$ Country dummies $_{c}+\beta_{3}$ Industry dummies $_{i}+\xi_{i, c}$

Standard deviations are computed using BK filtered data. The sample period is 1963 to 1999 . Three measures of financial development are used: private credit over GDP, total capitalization over GDP, and private credit instrumented with legal variables. Results with the dummy for high external-finance dependence are also reported. The first set of results shows the interaction of financial development with financial dependence. The second set of results shows the interaction of financial development with a dumy for high financial dependence. The row "differential impact of 50-percentage-point increase in financial development" considers the differential effect over high- and low-dependence industries of increasing the corresponding measure of development by 50 percent of GDP; the effect is measured as percentage of the median volatility in the sample. Industry and country dummies are not reported. Robust standard errors clustered by country are reported below the coefficients. Significance (two-sided): $* 10 \%, * * 5 \%, * * * 1 \%$.

Dependent Variable: St. Deviation (BK filter)

Measure of Financial Development

Independent Variables

Financial Development $X$

Financial Dependence

Financial Development X

High Financial Dependence

Adjusted $\mathrm{R}^{2}$

Number of observations

Differential impact of 50 percentage-point

increase in Financial Development
Total Capitalization (OLS)

Private Credit (2SLS)

Private Credit (OLS)

$-0.0114$

0.0046

$-0.0111$

0.0178

0.0091

$-0.0172$

0.0048

$-0.0085$

0.0027

$-0.0209$

0.0104

0.551

0.526

0.537

0.538

1407

0.551

1574

0.552

1574

$7 \%$

$13 \%$

$4 \%$

$7 \%$

$4 \%$

$16 \%$ 


\section{TABLE 3}

\section{The Differential Effect of Financial Development over Industrial Output Volatility:}

\section{Alternative Interactions and Controls}

The basic regression is the same as in Table 2, but with the addition of different interaction effects. Standard deviations are computed using the BK filter. See the Appendix for the description of the variables. The row "differential impact of 50-percentage-point increase in financial development" considers the differential effect over high- and low-dependence industries of increasing private credit by 50 percent of GDP; the effect is measured as percentage of the median volatility in the sample. Industry and country dummies are not reported. Robust standard errors clustered by country are reported below the coefficients. Significance (two-sided): $* 10 \%, * * 5 \%, * * * 1 \%$.

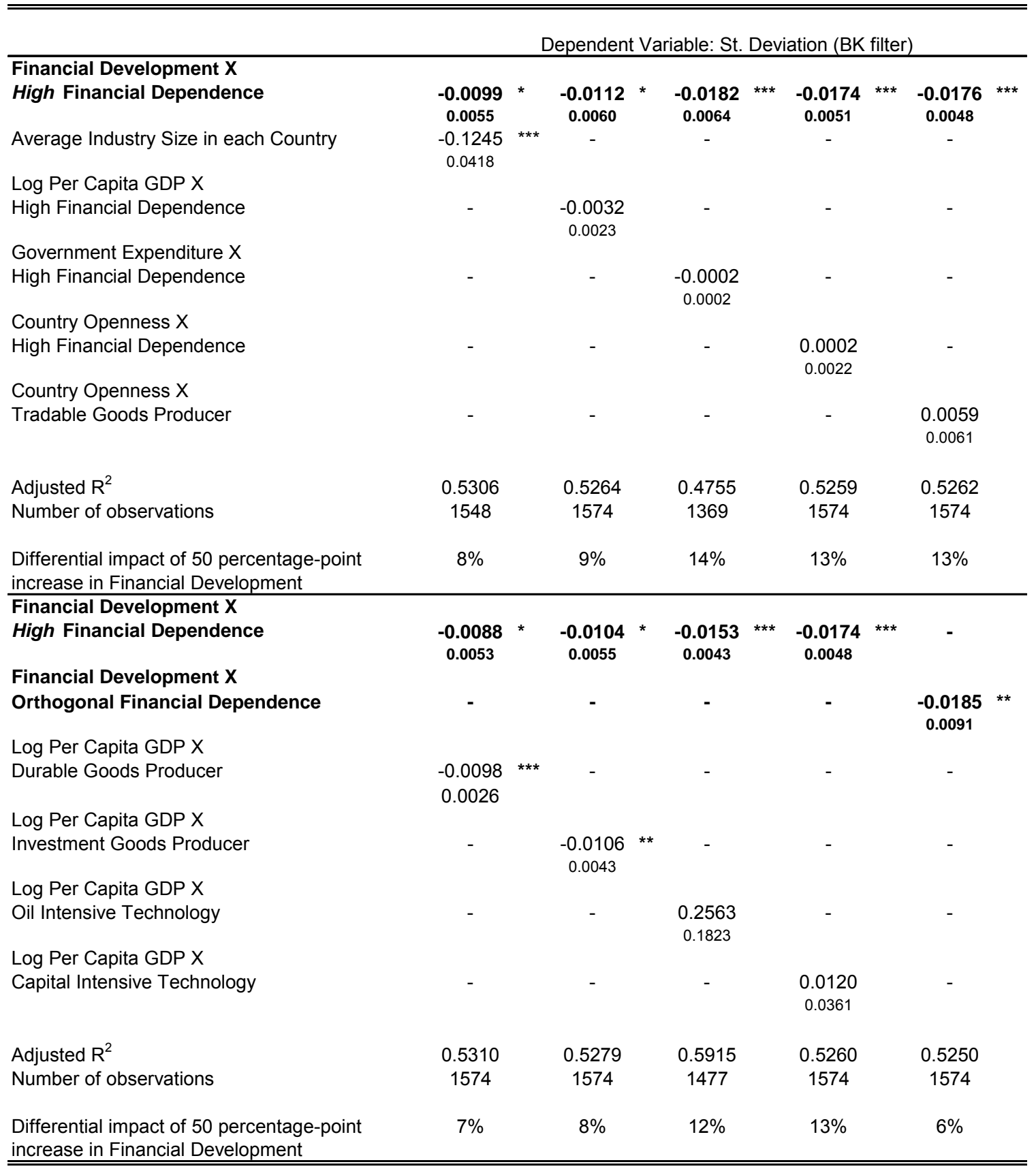




\section{TABLE 4}

\section{Variance Decomposition of Industrial Output Volatility}

Panel A specification: $\quad \sigma_{i c}^{2}=\beta_{i c}^{2} \sigma_{g d p, c}^{2}+\sigma_{\varepsilon, i c}^{2}$

The sample period is 1963 to 1999. The first column in Panel A shows the mean variance of industrial production. The second and third columns show the percentage of total variance that is attributed to systematic and idiosyncratic variance. Results for the sub-sample of countries that score below (above) the median of private credit to GDP are shown in the row Low (High) Private Credit Countries.

Panel B computes the difference in variance between low private credit countries and high private credit countries. The last row shows this difference as a percentage of the variance in each category for low private credit countries. Results are presented using BK filtered data.

\begin{tabular}{lccc}
\hline \hline Panel A & Total Variance & Systematic & Idiosyncratic \\
\hline Variance Decomposition & & & \\
Entire Sample & 0.0091 & $13 \%$ & $87 \%$ \\
Low Private Credit Countries & 0.0133 & $11 \%$ & $89 \%$ \\
High Private Credit Countries & 0.0049 & $19 \%$ & $81 \%$ \\
Panel B & & & \\
\hline Changes in Variance within Category & & & \\
Difference in Variance in Low Private Credit & 0.0084 & 0.0005 & 0.0079 \\
versus High Private Credit Countries & & & \\
& & $36 \%$ & $67 \%$ \\
Difference as \% of Variances in & $63 \%$ & & \\
Low Private Credit Countries & & & \\
& & & \\
\hline \hline
\end{tabular}




\section{TABLE 5}

\section{The Effect of Financial Development on the Correlation of Industrial Output with GDP}

specification: $\quad$ Correlation $_{i, c}=\alpha_{1}$ Financial development $_{c}+\alpha_{2}$ Country controls $_{c}+\alpha_{3}$ Industry dummies $_{i}+\varepsilon_{i, c}$

Correlations of industrial output with GDP are computed using Baxter-King (BK) filtered data and log changes in panels A and B, respectively. The sample period is 1963 to 1999. Financial development is measured with average private credit over GDP of the country. The sample of industries is split in two according to whether they score above or below the median external-finance dependence. The third column in each panel shows the p-value of the test that the effect of financial development is stronger in industries with high financial dependence. This p-value is obtained from a regression that includes both groups of industries. Robust standard errors clustered by country are reported below the coefficients. Industry dummies are not reported. Significance (two-sided): * 10\%, ** 5\%, *** $1 \%$.

Panel A

Panel B

A. Dep. Variable: Correlation with GDP (BK filter)

B. Dep. Variable: Correlation with GDP (log changes)

\begin{tabular}{|c|c|c|c|c|c|c|c|c|c|c|}
\hline \multirow[b]{2}{*}{ Independent Variables } & \multicolumn{4}{|c|}{ Industry Subsample } & & \multicolumn{4}{|c|}{ Industry Subsample } & \multirow[b]{2}{*}{$\begin{array}{c}\text { p-value } \\
\text { High > Low }\end{array}$} \\
\hline & $\begin{array}{c}\text { High } \\
\text { Financial } \\
\text { Dependence }\end{array}$ & & $\begin{array}{c}\text { Low } \\
\text { Financial } \\
\text { Dependence }\end{array}$ & & $\begin{array}{c}\text { p-value } \\
\text { High > Low }\end{array}$ & $\begin{array}{c}\text { High } \\
\text { Financial } \\
\text { Dependence }\end{array}$ & & $\begin{array}{c}\text { Low } \\
\text { Financial } \\
\text { Dependence }\end{array}$ & & \\
\hline Financial Development & $\begin{array}{c}0.2221 \\
0.1161\end{array}$ & * & $\begin{array}{c}0.0826 \\
0.1046\end{array}$ & & $0.3 \%$ & $\begin{array}{c}0.2095 \\
0.1233\end{array}$ & * & $\begin{array}{c}0.1971 \\
0.1270\end{array}$ & & $39.0 \%$ \\
\hline Log Per Capita GDP & $\begin{array}{c}0.1068 \\
0.0442\end{array}$ & ** & $\begin{array}{c}0.0829 \\
0.0394\end{array}$ & ** & $10.4 \%$ & $\begin{array}{c}0.0908 \\
0.0481\end{array}$ & * & $\begin{array}{c}0.0565 \\
0.0465\end{array}$ & & $2.1 \%$ \\
\hline Trade Openness & $\begin{array}{c}-0.1363 \\
0.0365\end{array}$ & $* * *$ & $\begin{array}{c}-0.0827 \\
0.0285\end{array}$ & $* * *$ & $0.5 \%$ & $\begin{array}{c}-0.1258 \\
0.0417\end{array}$ & $* * *$ & $\begin{array}{c}-0.1067 \\
0.0330\end{array}$ & $* * *$ & $11.2 \%$ \\
\hline Government Expenditure & $\begin{array}{c}0.0014 \\
0.0023\end{array}$ & & $\begin{array}{c}0.0016 \\
0.0020\end{array}$ & & $42.6 \%$ & $\begin{array}{c}0.0009 \\
0.0023\end{array}$ & & $\begin{array}{c}0.0026 \\
0.0330\end{array}$ & & $1.6 \%$ \\
\hline $\begin{array}{l}\text { Adjusted } \mathrm{R}^{2} \\
\text { Number of observations }\end{array}$ & $\begin{array}{c}0.291 \\
683\end{array}$ & & $\begin{array}{c}0.228 \\
686\end{array}$ & & & $\begin{array}{c}0.258 \\
683\end{array}$ & & $\begin{array}{c}0.234 \\
686\end{array}$ & & \\
\hline
\end{tabular}




\section{TABLE 6}

\section{The Differential Effect of Financial Development over Industrial Output Correlation with GDP}

specification: $\quad$ Correlation $_{i, c}=\beta_{1}\left(\right.$ Financial development $_{c} *$ Financial dependence $\left._{i}\right)+\beta_{2}$ Country dummies $_{c}+\beta_{3}$ Industry dummies $_{i}+\xi_{i, c}$

Correlations are computed using BK filtered data. The sample period is 1963 to 1999. Three measures of financial development are used: private credit over GDP, total capitalization over GDP, and private credit instrumented with legal variables. Results with the dummy for high external-finance dependence are also reported. The row "differential impact of 50-percentage-point increase in financial development" considers the differential effect over high- and low-dependence industries of increasing the corresponding measure of development by 50 percent of GDP; the effect is measured as percentage of the median correlation in the sample. Industry and country dummies are not reported. Robust standard errors clustered by country are reported below the coefficients. Significance (two-sided): * $10 \%, * * 5 \%, * * * 1 \%$.

\begin{tabular}{|c|c|c|c|c|c|c|c|c|c|c|c|}
\hline \multirow[t]{2}{*}{ Dependent Variable: Correlation with GDP } & \multicolumn{11}{|c|}{ Measure of Financial Development } \\
\hline & \multicolumn{3}{|c|}{ Private Credit (OLS) } & & \multicolumn{4}{|c|}{ Total Capitalization (OLS) } & \multicolumn{3}{|c|}{ Private Credit (2SLS) } \\
\hline Financial Dependence & $\begin{array}{l}0.1186 \\
0.0603\end{array}$ & ** & - & & $\begin{array}{l}0.0503 \\
0.0239\end{array}$ & ** & - & & $\begin{array}{l}0.1747 \\
0.1247\end{array}$ & - & \\
\hline $\begin{array}{l}\text { Financial Development X } \\
\text { High Financial Dependence }\end{array}$ & - & & $\begin{array}{l}0.1202 \\
0.0473\end{array}$ & ** & - & & $\begin{array}{l}0.0472 \\
0.0174\end{array}$ & $* * *$ & - & $\begin{array}{l}0.1678 \\
0.0594\end{array}$ & *** \\
\hline $\begin{array}{l}\text { Adjusted } \mathrm{R}^{2} \\
\text { Number of observations }\end{array}$ & $\begin{array}{c}0.5336 \\
1574\end{array}$ & & $\begin{array}{c}0.5358 \\
1574\end{array}$ & & $\begin{array}{c}0.5323 \\
1407\end{array}$ & & $\begin{array}{c}0.5341 \\
1407\end{array}$ & & $\begin{array}{c}0.5589 \\
1574\end{array}$ & $\begin{array}{c}0.5607 \\
1574\end{array}$ & \\
\hline $\begin{array}{l}\text { Differential impact of } 50 \text { percentage-point } \\
\text { increase in Financial Development }\end{array}$ & $9 \%$ & & $18 \%$ & & $4 \%$ & & $7 \%$ & & $13 \%$ & $25 \%$ & \\
\hline
\end{tabular}


TABLE 7

\section{The Differential Effect of Financial Development over Industrial Output Correlation with GDP: Alternative Interactions and Controls}

The basic regression is the same as in Table 6, but with the addition of different interaction effects. Correlations are computed using the BK filter. See the Appendix for a description of the variables. The row "differential impact of 50percentage-point increase in financial development" considers the differential effect over high- and low-dependence industries of increasing private credit by 50 percent of GDP; the effect is measured as percentage of the median correlation in the sample. Industry and country dummies are not reported. Robust standard errors clustered by country are reported below the coefficients. Significance (two-sided): * $10 \%, * * 5 \%, * * * 1 \%$.

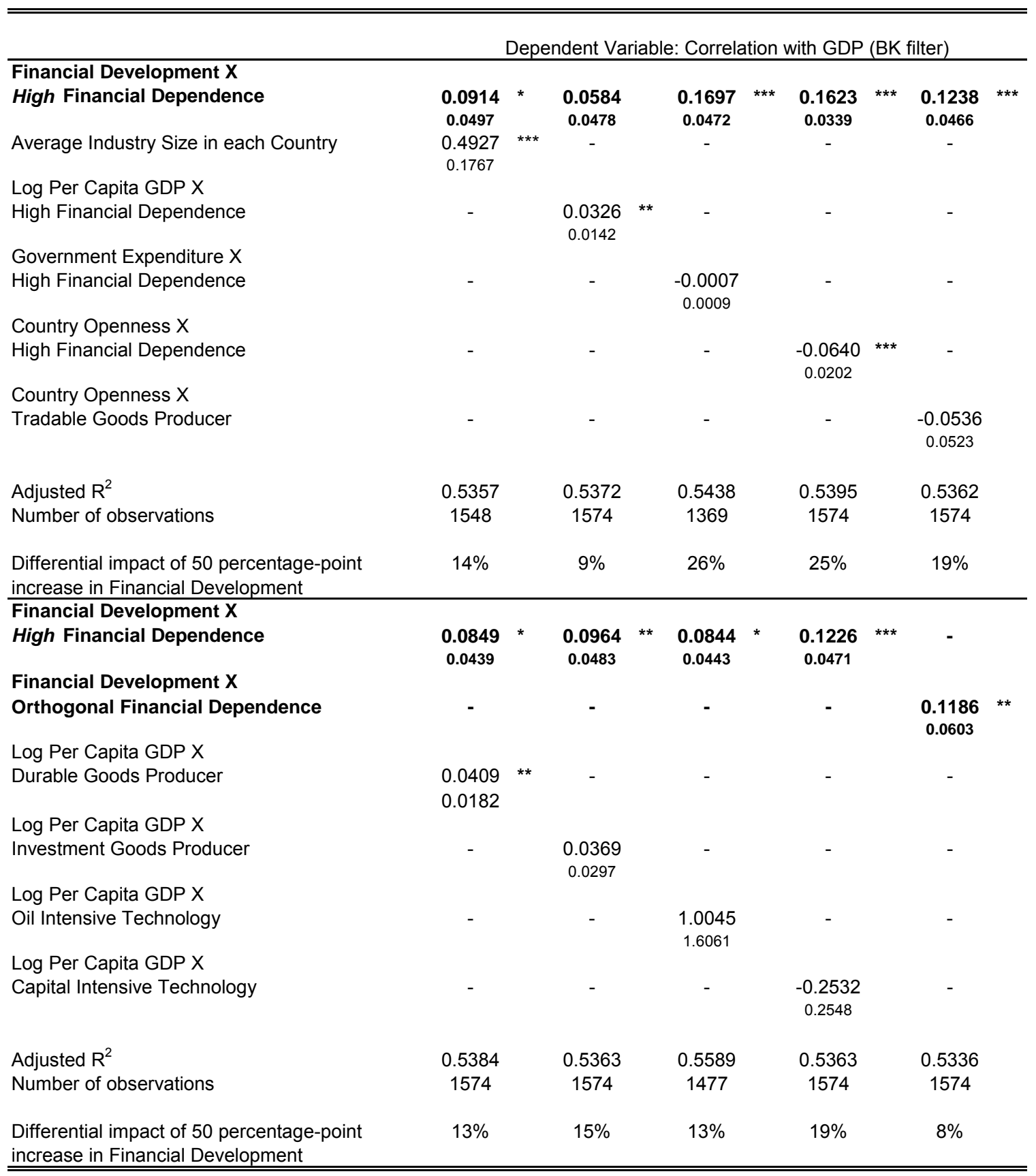




\section{TABLE 8}

\section{The Effect of Financial Development on the Volatility and Correlations of Output and Short-Term Debt in Firm-Level Data}

specification: $\quad$ St. deviation ${ }_{i, c, f}=\alpha_{1}$ Financial development $_{c}+\alpha_{2}$ Country controls $_{c}+\alpha_{3}$ Industry dummies $_{i}+\alpha_{4}$ Firm controls $_{i, c, f}+\varepsilon_{i, c, f}$

The sample period is 1991 to 2002. The dependent variables are: (A) Standard deviation of $\Delta \log (\operatorname{sales} /$ assets), (B) Covariance of $\Delta \log (\mathrm{sales} / \mathrm{assets})$ and $\Delta \log (\mathrm{short}$ term debt/assets), (C) Correlation of $\Delta \log$ (sales/assets) and $\Delta \log$ (short term debt/assets). Country controls include the log of per capita GDP, openness, and government expenditure. Firm controls include the average log of sales, average profitability and average tangibility for each firm during the sample period. Results are reported for two sub-samples of firms corresponding to industries with high and low financial dependence according to the Rajan-Zingales index. The last row reports the p-value of the test that the effect of financial development is larger (in absolute value) in the group of highly dependent firms. All firm variables are Winsorized at the $1 \%$ and $99 \%$ level. Industry dummies are not reported. Robust standard errors clustered by country-industry units are reported below the coefficients. Significance (two-sided): * $10 \%$, $* * 5 \%, * * * 1 \%$.

\begin{tabular}{|c|c|c|c|c|c|c|c|c|c|c|c|c|}
\hline \multirow[b]{3}{*}{ Independent Variables } & \multicolumn{4}{|c|}{$\begin{array}{c}\text { Panel A } \\
\text { Dep. Variable: St. Deviation Sales }\end{array}$} & \multicolumn{4}{|c|}{$\begin{array}{c}\text { Panel B } \\
\text { Dep. Variable: Covariance Sales-Debt }\end{array}$} & \multicolumn{4}{|c|}{$\begin{array}{c}\text { Panel C } \\
\text { Dep. Variable: Correlation Sales-Debt }\end{array}$} \\
\hline & \multicolumn{4}{|c|}{ Industry Subsample } & \multicolumn{4}{|c|}{ Industry Subsample } & \multicolumn{4}{|c|}{ Industry Subsample } \\
\hline & $\begin{array}{c}\text { High } \\
\text { Financial } \\
\text { Dependence }\end{array}$ & & $\begin{array}{c}\text { Low } \\
\text { Financial } \\
\text { Dependeno } \\
\end{array}$ & & $\begin{array}{c}\text { High } \\
\text { Financial } \\
\text { Dependence }\end{array}$ & & $\begin{array}{c}\text { Low } \\
\text { Financial } \\
\text { Dependenc } \\
\end{array}$ & & $\begin{array}{c}\text { High } \\
\text { Financial } \\
\text { Dependenc } \\
\end{array}$ & & $\begin{array}{c}\text { Low } \\
\text { Financial } \\
\text { Dependence }\end{array}$ & \\
\hline \multirow[t]{2}{*}{ Financial Development } & -0.1635 & $* * *$ & -0.1928 & *** & -0.0380 & $* * *$ & -0.0155 & & -0.1837 & ** & 0.1059 & \\
\hline & 0.0294 & & 0.0361 & & 0.0129 & & 0.0126 & & 0.0763 & & 0.0700 & \\
\hline \multirow[t]{2}{*}{ Log Per Capita GDP } & -0.0196 & * & -0.0076 & & 0.0086 & * & 0.0064 & ** & 0.1028 & $* * *$ & 0.0549 & $* * *$ \\
\hline & 0.0113 & & 0.0088 & & 0.0049 & & 0.0030 & & 0.0293 & & 0.0210 & \\
\hline \multirow[t]{2}{*}{ Openness } & -0.0017 & & -0.0178 & * & -0.0096 & $* * *$ & -0.0092 & $* * *$ & -0.0058 & & 0.0187 & \\
\hline & 0.0075 & & 0.0098 & & 0.0037 & & 0.0034 & & 0.0231 & & 0.0200 & \\
\hline \multirow[t]{2}{*}{ Government Expenditure } & -0.0008 & & 0.0009 & & -0.0003 & & -0.0001 & & -0.0050 & $* * *$ & -0.0052 & *** \\
\hline & 0.0007 & & 0.0006 & & 0.0004 & & 0.0002 & & 0.0018 & & 0.0015 & \\
\hline \multirow[t]{2}{*}{ Average Log Sales } & -0.0183 & $* * *$ & -0.0174 & $* * *$ & -0.0050 & $* * *$ & -0.0045 & $* * *$ & 0.0003 & & -0.0072 & * \\
\hline & 0.0022 & & 0.0022 & & 0.0010 & & 0.0008 & & 0.0052 & & 0.0042 & \\
\hline \multirow[t]{2}{*}{ Average Profitability } & -0.7841 & $* * *$ & -1.1316 & $* * *$ & -0.2985 & $* * *$ & -0.3102 & $* * *$ & -0.3841 & $* * *$ & -0.4527 & $* * *$ \\
\hline & 0.0651 & & 0.1425 & & 0.0341 & & 0.0711 & & 0.0970 & & 0.0949 & \\
\hline \multirow[t]{2}{*}{ Average Tangibility } & -0.1077 & $* * *$ & -0.0859 & $* * *$ & -0.0326 & & -0.0372 & $* * *$ & -0.1994 & ** & -0.0253 & \\
\hline & 0.0390 & & 0.0303 & & 0.0291 & & 0.0142 & & 0.0994 & & 0.0741 & \\
\hline Adjusted $\mathrm{R}^{2}$ & 0.371 & & 0.475 & & 0.161 & & 0.208 & & 0.030 & & 0.040 & \\
\hline Number of observations & 2821 & & 2830 & & 2821 & & 2830 & & 2821 & & 2830 & \\
\hline P-value High < Low & & & $26 \%$ & & & & $21 \%$ & & & & $1 \%$ & \\
\hline
\end{tabular}


TABLE A.1 Industry Characteristics

\begin{tabular}{|c|c|c|c|c|c|c|c|c|c|}
\hline Industry & $\begin{array}{l}\text { ISIC3 } \\
\text { Code }\end{array}$ & $\begin{array}{c}\text { External } \\
\text { Finance } \\
\text { Dependence }\end{array}$ & $\begin{array}{l}\text { Orthogonal } \\
\text { External } \\
\text { Finance } \\
\text { Dependence }\end{array}$ & $\begin{array}{c}\text { High } \\
\text { External } \\
\text { Finance } \\
\text { Dependence }\end{array}$ & $\begin{array}{c}\text { Investment } \\
\text { Goods } \\
\text { Producer }\end{array}$ & $\begin{array}{c}\text { Durable } \\
\text { Goods } \\
\text { Producer }\end{array}$ & $\begin{array}{l}\text { Tradable } \\
\text { Goods } \\
\text { Producer }\end{array}$ & $\begin{array}{c}\text { Capital } \\
\text { Intensive } \\
\text { Technology }\end{array}$ & $\begin{array}{c}\text { Oil } \\
\text { Intensive } \\
\text { Technology }\end{array}$ \\
\hline Food products & 311 & 0.0973 & 0.0468 & 0 & 0 & 0 & 0.1576 & 0.0616 & 0.0026 \\
\hline Beverages & 313 & 0.0103 & -0.0406 & 0 & 0 & 0 & 0.1576 & 0.0620 & 0.0026 \\
\hline Tobacco & 314 & -0.2884 & -0.2923 & 0 & 0 & 0 & 0.1569 & 0.0181 & 0.0027 \\
\hline Textiles & 321 & 0.1802 & 0.0690 & 1 & 0.0950 & 0.5 & 0.4436 & 0.0726 & 0.0028 \\
\hline Wearing apparel, except footwear & 322 & 0.0298 & 0.0336 & 0 & 0 & 0.5 & 0.4046 & 0.0189 & 0.0017 \\
\hline Leather products & 323 & -0.0892 & -0.1162 & 0 & 0 & 0.5 & 0.4948 & 0.0324 & 0.0036 \\
\hline Footwear, except rubber or plastic & 324 & -0.1694 & -0.1811 & 0 & 0 & 0.5 & 0.4948 & 0.0181 & 0.0036 \\
\hline Wood products, except furniture & 331 & 0.2818 & -0.1381 & 1 & 0.7513 & 1 & 0.5598 & 0.0653 & 0.0051 \\
\hline Furniture, except metal & 332 & 0.1981 & 0.0197 & 1 & 0.4647 & 1 & 0.2230 & 0.0390 & 0.0051 \\
\hline Paper and products & 341 & 0.0848 & -0.1151 & 0 & 0 & 0 & 0.5702 & 0.1315 & 0.0073 \\
\hline Printing and publishing & 342 & 0.0970 & 0.1198 & 0 & 0 & 0.5 & 0.1072 & 0.0515 & 0.0024 \\
\hline Industrial chemicals & 351 & 0.1612 & -0.1228 & 1 & 0.0618 & 0 & 0.8811 & 0.1267 & 0.0204 \\
\hline Other chemicals & 352 & 0.0726 & -0.1398 & 0 & 0.0618 & 0 & 0.8811 & 0.0597 & 0.0204 \\
\hline Petroleum refineries & 353 & 0.0488 & -0.1585 & 0 & 0 & 0 & 0.2337 & 0.1955 & . \\
\hline Miscellaneous petroleum and coal products & 354 & 0.0617 & -0.0160 & 0 & 0 & 0 & 0.2337 & 0.0741 & . \\
\hline Rubber products & 355 & 0.1496 & 0.0129 & 1 & 0.0162 & 0 & 0.5623 & 0.0656 & 0.0029 \\
\hline Plastic products & 356 & 1.1401 & 0.9439 & 1 & 0.0081 & 0 & 0.7807 & 0.0883 & 0.0034 \\
\hline Pottery, china, earthenware & 361 & -0.2979 & -0.3335 & 0 & 0 & 1 & 0.7060 & 0.0546 & 0.0116 \\
\hline Glass and products & 362 & 0.2971 & 0.2274 & 1 & 0 & 1 & 0.6859 & 0.0899 & 0.0061 \\
\hline Other non-metallic mineral products & 369 & 0.0760 & -0.0811 & 0 & 0 & 0 & 0.7060 & 0.0684 & 0.0116 \\
\hline Iron and steel & 371 & 0.0370 & -0.1243 & 0 & 0.0694 & 1 & 0.9189 & 0.1017 & 0.0058 \\
\hline Non-ferrous metals & 372 & 0.0995 & -0.1934 & 1 & 0.3046 & 1 & 0.9585 & 0.1012 & 0.0056 \\
\hline Fabricated metal products & 381 & 0.2013 & -0.0692 & 1 & 0.4740 & 1 & 0.6213 & 0.0531 & 0.0028 \\
\hline Machinery, except electrical & 382 & 0.3005 & -0.1815 & 1 & 0.9077 & 1 & 0.4854 & 0.0582 & 0.0028 \\
\hline Machinery, electric & 383 & 0.5147 & 0.2294 & 1 & 0.4730 & 1 & 0.5678 & 0.0765 & 0.0017 \\
\hline Transport equipment & 384 & 0.2665 & -0.0263 & 1 & 0.5354 & 1 & 0.4564 & 0.0714 & 0.0014 \\
\hline Professional and scientific equipment & 385 & 0.6805 & 0.3679 & 1 & 0.6295 & 1 & 0.4011 & 0.0525 & 0.0020 \\
\hline Other manufactured products & 390 & 0.2955 & 0.2594 & 1 & 0.1370 & 1 & 0.3973 & 0.0393 & 0.0051 \\
\hline
\end{tabular}


TABLE A.2 Sample Characteristics: Industry Data

\begin{tabular}{|c|c|c|}
\hline $\begin{array}{l}\text { ISIC3 } \\
\text { Code }\end{array}$ & $\begin{array}{l}\text { Total } \\
\text { Obs. }\end{array}$ & $\begin{array}{c}\text { No. of } \\
\text { Countries }\end{array}$ \\
\hline 311 & 2,155 & 59 \\
\hline 313 & 2,157 & 59 \\
\hline 314 & 2,112 & 58 \\
\hline 321 & 2,148 & 59 \\
\hline 322 & 2,139 & 59 \\
\hline 323 & 1,993 & 55 \\
\hline 324 & 2,019 & 56 \\
\hline 331 & 2,138 & 59 \\
\hline 332 & 2,138 & 59 \\
\hline 341 & 2,152 & 59 \\
\hline 342 & 2,150 & 59 \\
\hline 351 & 2,145 & 59 \\
\hline 352 & 2,111 & 58 \\
\hline 353 & 2,020 & 56 \\
\hline 354 & 1,467 & 41 \\
\hline 355 & 2,057 & 57 \\
\hline 356 & 2,055 & 57 \\
\hline 361 & 2,106 & 58 \\
\hline 362 & 2,043 & 56 \\
\hline 369 & 2,154 & 59 \\
\hline 371 & 1,882 & 52 \\
\hline 372 & 1,806 & 50 \\
\hline 381 & 2,114 & 58 \\
\hline 382 & 2,098 & 58 \\
\hline 383 & 2,142 & 59 \\
\hline 384 & 2,096 & 58 \\
\hline 385 & 1,678 & 47 \\
\hline 390 & 1,803 & 50 \\
\hline
\end{tabular}

\begin{tabular}{ll}
\hline \hline Year & Total \\
& Obs. \\
\hline 1963 & 1,493 \\
1964 & 1,497 \\
1965 & 1,530 \\
1966 & 1,535 \\
1967 & 1,537 \\
1968 & 1,568 \\
1969 & 1,568 \\
1970 & 1,571 \\
1971 & 1,572 \\
1972 & 1,573 \\
1973 & 1,573 \\
1974 & 1,574 \\
1975 & 1,574 \\
1976 & 1,574 \\
1977 & 1,574 \\
1978 & 1,574 \\
1979 & 1,574 \\
1980 & 1,574 \\
1981 & 1,574 \\
1982 & 1,574 \\
1983 & 1,574 \\
1984 & 1,574 \\
1985 & 1,574 \\
1986 & 1,574 \\
1987 & 1,574 \\
1988 & 1,574 \\
1989 & 1,574 \\
1990 & 1,574 \\
1991 & 1,539 \\
1992 & 1,529 \\
1993 & 1,509 \\
1994 & 1,509 \\
1995 & 1,508 \\
1996 & 1,506 \\
1997 & 1,454 \\
1998 & 1,420 \\
1999 & 1,329 \\
\hline & \\
\hline & \\
\hline & \\
193
\end{tabular}

\begin{tabular}{ccc}
\hline \hline Country & Total & No. of \\
& Obs. & Industries
\end{tabular}

\begin{tabular}{|c|c|c|}
\hline ALGERIA & 978 & 27 \\
\hline ARGENTINA & 1,036 & 28 \\
\hline AUSTRALIA & 1,036 & 28 \\
\hline AUSTRIA & 1,036 & 28 \\
\hline BOLIVIA & 999 & 27 \\
\hline BRAZIL & 956 & 26 \\
\hline CANADA & 978 & 28 \\
\hline CHILE & 1,036 & 28 \\
\hline COLOMBIA & 1,036 & 28 \\
\hline COSTA RICA & 864 & 24 \\
\hline DENMARK & 1,036 & 28 \\
\hline ECUADOR & 994 & 27 \\
\hline EGYPT & 980 & 28 \\
\hline EL SALVADOR & 996 & 27 \\
\hline FINLAND & 1,036 & 28 \\
\hline FRANCE & 1,036 & 28 \\
\hline GHANA & 957 & 27 \\
\hline GREECE & 1,036 & 28 \\
\hline HONDURAS & 882 & 24 \\
\hline HONG KONG & 924 & 26 \\
\hline HUNGARY & 1,029 & 28 \\
\hline INDIA & 1,036 & 28 \\
\hline INDONESIA & 953 & 26 \\
\hline IRELAND & 976 & 27 \\
\hline ISRAEL & 1,014 & 28 \\
\hline ITALY & 1,036 & 28 \\
\hline JAPAN & 1,033 & 28 \\
\hline KENYA & 864 & 24 \\
\hline KOREA, REP & 1,022 & 28 \\
\hline MALAYSIA & 962 & 26 \\
\hline MEXICO & 1,036 & 28 \\
\hline MOROCCO & 925 & 25 \\
\hline NETHERLANDS & 925 & 25 \\
\hline NEW ZEALAND & 954 & 26 \\
\hline NIGERIA & 638 & 20 \\
\hline NORWAY & 1,036 & 28 \\
\hline PANAMA & 1,034 & 28 \\
\hline PARAGUAY & 996 & 27 \\
\hline PERU & 1,036 & 28 \\
\hline PHILIPPINES & 952 & 28 \\
\hline PORTUGAL & 1,036 & 28 \\
\hline SENEGAL & 481 & 13 \\
\hline SINGAPORE & 950 & 26 \\
\hline SOUTH AFRICA & 1,032 & 28 \\
\hline SPAIN & 1,036 & 28 \\
\hline SRI LANKA & 936 & 26 \\
\hline SWEDEN & 1,036 & 28 \\
\hline SWITZERLAND & 1,015 & 28 \\
\hline SYRIAN ARAB REPUBLIC & 952 & 26 \\
\hline THAILAND & 765 & 24 \\
\hline TRINIDAD\&TOBAGO & 925 & 25 \\
\hline TUNISIA & 921 & 25 \\
\hline TURKEY & 896 & 28 \\
\hline UNITED KINGDOM & 1,036 & 28 \\
\hline UNITED STATES & 1,036 & 28 \\
\hline URUGUAY & 1,034 & 28 \\
\hline VENEZUELA & 786 & 28 \\
\hline ZAMBIA & 961 & 26 \\
\hline ZIMBABWE & 955 & 26 \\
\hline
\end{tabular}


TABLE A.3 Sample Characteristics: Firm-Level Data

\begin{tabular}{rr}
\hline \hline $\begin{array}{r}\text { ISIC3 } \\
\text { Code }\end{array}$ & \multicolumn{1}{r}{$\begin{array}{r}\text { Total } \\
\text { Obs. }\end{array}$} \\
\hline 311 & 3,169 \\
313 & 1,174 \\
314 & 199 \\
321 & 1,464 \\
322 & 1,081 \\
323 & 107 \\
324 & 202 \\
331 & 726 \\
332 & 690 \\
341 & 1,811 \\
342 & 1,618 \\
351 & 5,576 \\
352 & 727 \\
353 & 795 \\
354 & 69 \\
355 & 597 \\
356 & 781 \\
361 & 192 \\
362 & 343 \\
369 & 1,668 \\
371 & 1,797 \\
372 & 1,193 \\
381 & 1,996 \\
382 & 3,652 \\
383 & 8,530 \\
384 & 2,887 \\
385 & 3,045 \\
390 & 841 \\
& \\
\hline \hline &
\end{tabular}

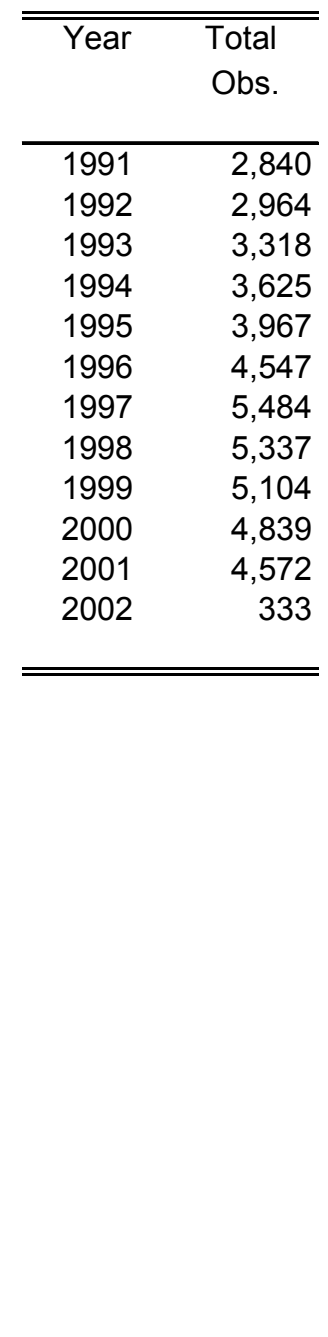

\begin{tabular}{lrr}
\hline \multicolumn{1}{c}{ Country } & Total & No. of \\
& Obs. & Firms \\
& & \\
\hline ARGENTINA & 100 & 15 \\
AUSTRALIA & 855 & 98 \\
AUSTRIA & 371 & 49 \\
BRAZIL & 621 & 83 \\
CANADA & 1,540 & 183 \\
CHILE & 188 & 33 \\
COLOMBIA & 95 & 15 \\
DENMARK & 539 & 63 \\
EGYPT & 15 & 3 \\
FINLAND & 438 & 57 \\
FRANCE & 1,942 & 243 \\
GREECE & 143 & 24 \\
HONG KONG & 286 & 43 \\
HUNGARY & 43 & 8 \\
INDIA & 936 & 152 \\
INDONESIA & 379 & 52 \\
IRELAND & 201 & 21 \\
ISRAEL & 172 & 22 \\
ITALY & 648 & 89 \\
JAPAN & 10,918 & 1,390 \\
KOREA, REP & 295 & 53 \\
MALAYSIA & 1,343 & 191 \\
MEXICO & 243 & 32 \\
MOROCCO & 5 & 1 \\
NETHERLANDS & 670 & 81 \\
NEW ZEALAND & 128 & 18 \\
NORWAY & 308 & 40 \\
PANAMA & 21 & 2 \\
PERU & 31 & 6 \\
PHILIPPINES & 116 & 19 \\
PORTUGAL & 158 & 21 \\
SINGAPORE & 667 & 94 \\
SOUTH AFRICA & 221 & 28 \\
SPAIN & 464 & 55 \\
SWEDEN & 644 & 91 \\
SWITZERLAND & 729 & 92 \\
THAILAND & 814 & 117 \\
TURKEY & 158 & 24 \\
UNITED KINGDOM & 345 \\
UNITED STATES & 15,735 & 1,714 \\
VENEZUELA & & 5 \\
ZIMBABWE & & \\
& & \\
\hline
\end{tabular}




\section{TABLE A.4 Summary Statistics}

\begin{tabular}{|c|c|c|c|c|c|c|}
\hline & Total No. Obs. & Mean & Median & St. Dev. & Min & Max \\
\hline \multicolumn{7}{|l|}{ Industry Data } \\
\hline Private Credit/ GDP & 1574 & 0.349 & 0.283 & 0.261 & 0.051 & 1.424 \\
\hline Total Capitalization/ GDP & 1407 & 0.770 & 0.660 & 0.597 & 0.149 & 2.711 \\
\hline Rule of Law & 1574 & 66.5 & 68.1 & 25.6 & 6.8 & 100.0 \\
\hline Corruption & 1574 & 6.2 & 5.3 & 2.4 & 1.7 & 10.0 \\
\hline Government Expenditures/ GDP & 1369 & 0.287 & 0.274 & 0.107 & 0.107 & 0.553 \\
\hline Openness (log Frankel-Romer index) & 1574 & 3.859 & 3.878 & 0.572 & 2.553 & 5.780 \\
\hline Median per capita GDP 1960-2000 & 1574 & 5598 & 3897 & 4119 & 843 & 15290 \\
\hline External Finance Dependence & 1574 & 0.160 & 0.097 & 0.275 & -0.298 & 1.140 \\
\hline Orthogonal External Finance Dependence & 1574 & -0.002 & -0.069 & 0.243 & -0.333 & 0.944 \\
\hline Investment Goods Producer & 1574 & 0.178 & 0.008 & 0.267 & 0.000 & 0.908 \\
\hline Durable Goods Producer & 1574 & 0.513 & 0.500 & 0.452 & 0.000 & 1.000 \\
\hline Tradable Goods Producer & 1574 & 0.509 & 0.495 & 0.243 & 0.107 & 0.958 \\
\hline Capital-intensive Technology & 1574 & 0.069 & 0.062 & 0.037 & 0.018 & 0.196 \\
\hline Oil-intensive Technology & 1477 & 0.006 & 0.003 & 0.005 & 0.001 & 0.020 \\
\hline Average Industry Size & 1548 & 0.038 & 0.024 & 0.045 & 0.000 & 0.435 \\
\hline Correlation with GDP (BK filter) & 1574 & 0.331 & 0.332 & 0.283 & -0.650 & 0.926 \\
\hline Correlation with GDP (log changes) & 1574 & 0.353 & 0.360 & 0.263 & -0.661 & 0.898 \\
\hline Standard Deviation (BK filter) & 1574 & 0.080 & 0.066 & 0.052 & 0.009 & 0.564 \\
\hline Standard Deviation (log changes) & 1574 & 0.133 & 0.111 & 0.083 & 0.016 & 0.822 \\
\hline Total Variance (BK filter) & 1574 & 0.009 & 0.004 & 0.017 & 0.000 & 0.319 \\
\hline Systematic Variance (BK filter) & 1574 & 0.001 & 0.000 & 0.002 & 0.000 & 0.038 \\
\hline Idiosyncratic Variance (BK filter) & 1574 & 0.008 & 0.003 & 0.017 & 0.000 & 0.308 \\
\hline \multicolumn{7}{|l|}{ Firm Data (Winsorized at 1\%-99\%) } \\
\hline St. Deviation $\Delta \log ($ sales/assets) & 5773 & 0.202 & 0.138 & 0.209 & 0.029 & 1.340 \\
\hline Covariance $\Delta \log$ (sales/assets) and $\Delta \log$ (short term debt/assets) & 5773 & 0.018 & 0.002 & 0.099 & -0.237 & 0.628 \\
\hline Correlation $\Delta \log ($ sales/assets) and $\Delta \log ($ short term debt/assets) & 5773 & 0.074 & 0.100 & 0.509 & -0.950 & 0.961 \\
\hline Average Log Sales & 5773 & 14.385 & 14.064 & 2.994 & 8.000 & 21.796 \\
\hline Average Profitability & 5748 & 0.098 & 0.105 & 0.104 & -0.432 & 0.317 \\
\hline Average Tangibility & 5773 & 0.322 & 0.305 & 0.163 & 0.040 & 0.759 \\
\hline
\end{tabular}

